\title{
A Model for Teachers' Productivity Based on Positive Organizational Behavior Approach in the Ministry of Education
}

Ehsan Rajabian ${ }^{1}$ Ph.D. in Public Administration, Qazvin Branch, Islamic Azad University, Qazvin, Iran, (Corresponding Author).

Sayed Mehdi Alvani ${ }^{2}$ Professor, Department of Public Administration, Qazvin Branch, Islamic Azad University, Qazvin, Iran.
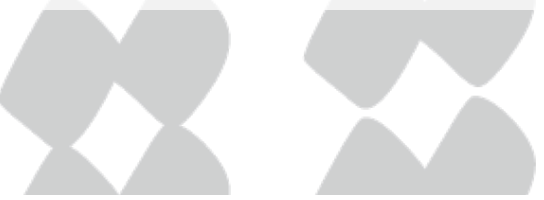

\begin{abstract}
The purpose of this study is to present a model for teachers' productivity with positive organizational behavior approach. The research method was mixed. In the qualitative strategy, meta-synthesis method and fuzzy Delphi were employed, and in the quantitative strategy, descriptive-survey method was used. At the fuzzy Delphi stage, 12 education and management faculty members of some state universities, Payame Noor University and Islamic Azad University and at the quantity side, a statistical sample of 384 primary and secondary school teachers were selected. Using the meta-synthesis method, 3 categories, 4 subcategories, 22 concepts and 79 indicators were identified. The model we obtained is founded on three main constructs: a. input construct, including cognitive an behavioral factors, b. process construct, including planning and deploying, creating appropriate learning environment, and c. output construct, including effectiveness and efficiency. In terms of confirmatory factor analysis, the second order has a good fit.
\end{abstract}

Keywords: Education, Productivity, Positive Organizational Behavior, Teaching-learning Process, Teachers.

DOI: $10.29252 / j m d p .33 .2 .193$

1. ehsan.rajabian@qiau.ac.ir

2.alvani@qiau.ac.ir 
عنوان مقاله: ارائه مدل بهرهورى معلمان با رويكرد رفتار

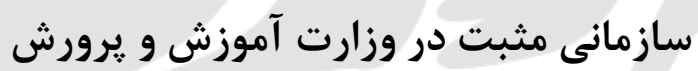

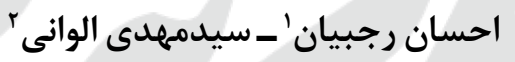

مقاله يثوهشى

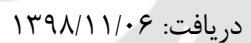

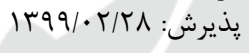

\section{جكيده:}

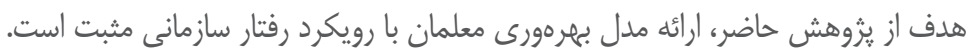

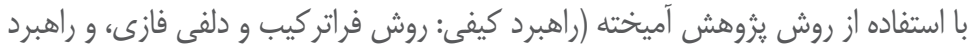

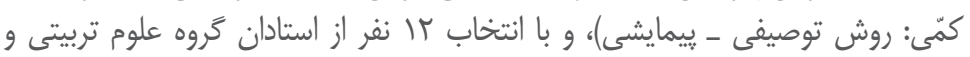

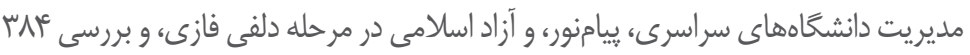

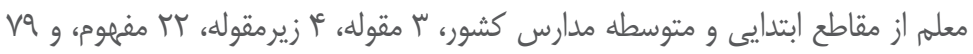

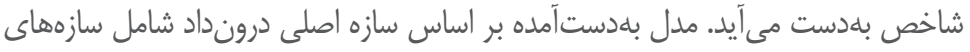

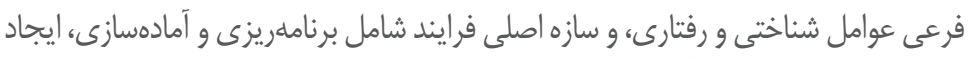

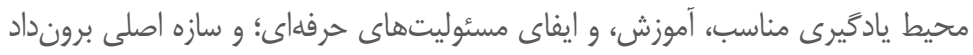

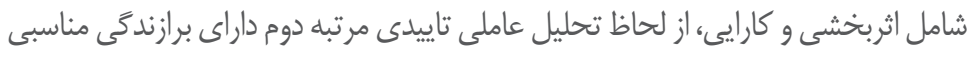
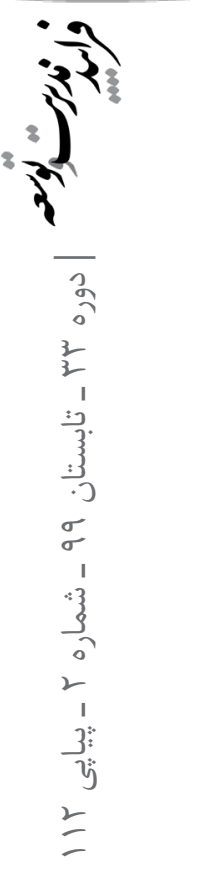

كليدوازهها: آموزش و يرورش، بهروورى، رفتار سازمانى مثبت،

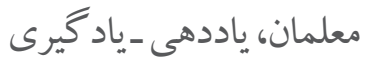

ا. دانش آموخته دكترى گروه مديريت دولتى، واحد قزوين، دانشكاه آزاد اسلامى، قزوين، اير ان (نويسنده ehsan.rajabian@qiau.ac.ir

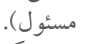

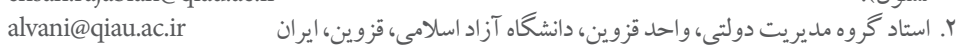




\section{مقدمه}

در هر كشور، يكى از بنيادىترين نظامهايى كه اثر عميقى بر روند رشد و توسعه كشور در كليه

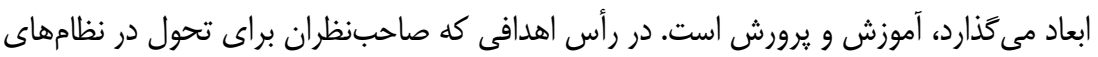
تعليم و تربيت مطرح مى كنند، معلم را نقطه اتكاى هر تغيير و تحولى مى دانند (ميرغفورى و صيادى، VAY (ا). "انقش معلم (مربى) به عنوان هدايت كننده و اسوهاى امين و بصير در فرايند تعليه و تربيت، و موثرترين عنصر در تحقق ماموريتهاى نظام تعليم و تربيت رسمى عمومى استه

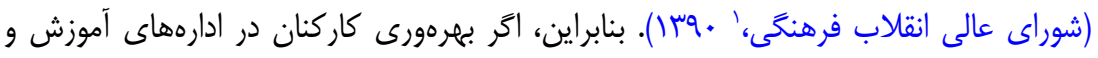
يرورش افزايش يابد، يويايى در تمام ابعاد جامعه را به دنبال دارد. ابر اساس گزارش رسمى سازمان آسيايى بهرهورى، سهرم بهرهورى نيروى انسانى ايران در توليد ناخالص ملّى بسيار نغران كننده

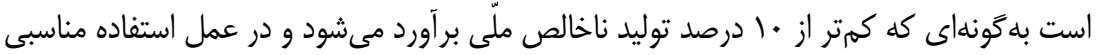

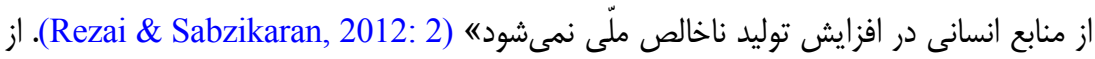

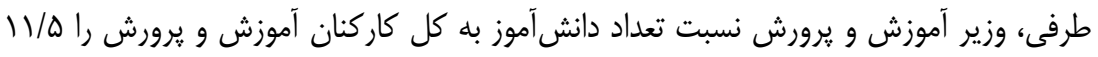
درصد بيان مى كند كه اين عدد بيانگر بهرهورى پايين منابع انسانى در آموزش و يرورش است (مركز اطلاعرسانى و روابط عمومى وزارت آموزش و يرورش، عهبا)ج. بر اساس شواهد موجود، روشن است كه ميزان بهرهورى در كشور، و بهطور خاص در نظام آموزش و يرورش و منابع انسانى آن از سطح مناسبى برخوردار نيست.

با بررسى ادبيات يزوهش در زمينه تعاريف بهرهورى مىتوان دريافت كه هرجه در زمان به جلو حركت شود، مفهوم بهرهورى از معيارهاى عينى به ذهنى تسرى مىيابد. برخى رويدادها و نمونهها

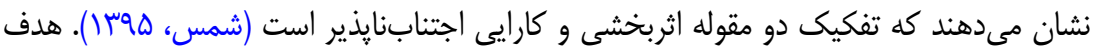
اصلى مديريت منابع انسانى بيشينهسازى بهرهورى شركتها از طريق بهينهسازى اثربخشى و

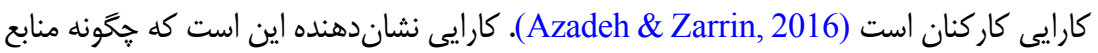
در فرايند دَر گَونسازى بلخوبى استفاده مىشوند. اثربخشى توانايى رسيدن به اهداف مطلوب يا ميزان دستيابى به نتايج مطلوب است (Tangen, 2005) و عامل بهرهورى معيارى براى ارزيابى 
عملكرد و تعيين ميزان موفقيت يا نبود موفقيت در رسيدن به هدفهاى سازمان با صرف كمترين

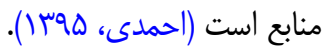

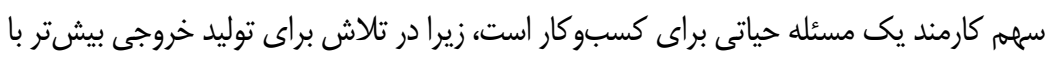

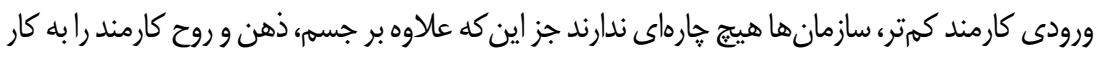

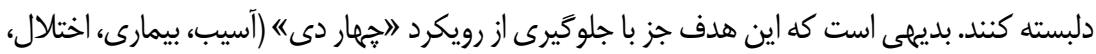

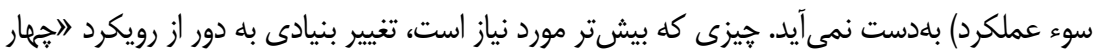
دى " است و اين جايى است كه رفتار سازمانى مثبت ظاهر مى شود (Bakker \& Schaufeli, 2008). در رويكرد جديد رفتار سازمانى مثبت توجه به نقاط مثبت و خوبىهاى رفتار آنتار آدمى است كه در سازمان

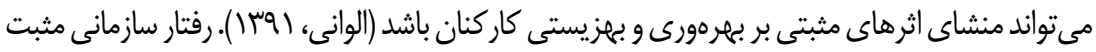
به عنوان "امطالعه و كاربرد مثبت كرايى در نقاط قوت منابع انسانى و ظرفيتهاى روانشناختى است كهان

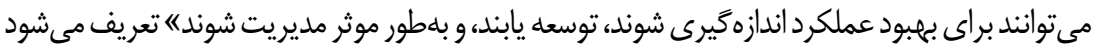
.(Luthans et al., 2007: 542)

با توجه به بررسى جامع در ادبيات يزوهش و مدلهاى بهرهورى منابع انسانى (الوانى و احمدى،

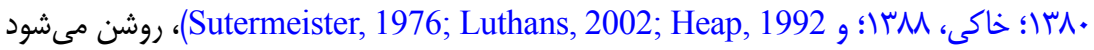
كه شكاف يُوهشى وجود دارد كه در تمامى مدلها به صورت غالب بالب با تعقل ابزارى يا كاربردى به بهروورى منابع انسانى برداخته مى شود و يزوهشى با رويكرد تعقل ارزشى يا جوهرى به مقوله

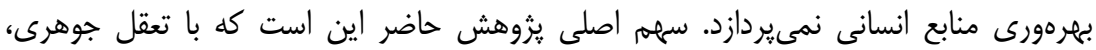

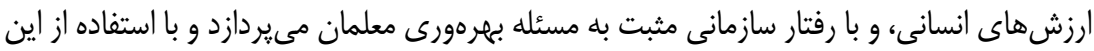

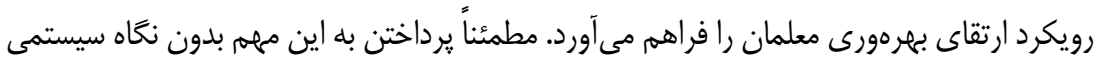
و جامع امكانيذير نيست. بر اساس تعريف جديد در اين يزوهش با ديدكاه سيستمى، عوامل رفتار

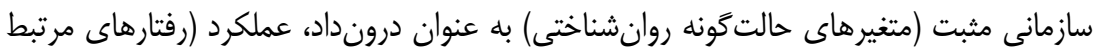

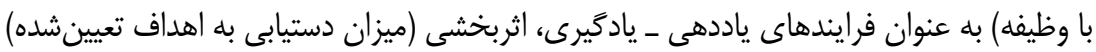

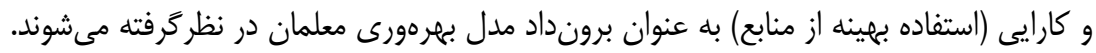

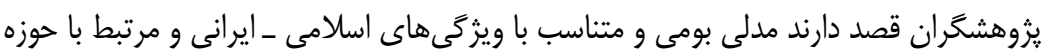
تعليم و تربيت در جهت افزايش بهرهورى و بهزيستى معلمان وزارت آموزش و يرورش، در راستاى

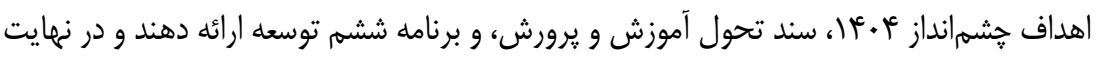
ييشنهادها و راهكار هايى كاربردى براى بهبود بهرهورى معلمان بيان كنند. 


\section{مبانى نظرى يزوهش}

براى نخستين بار كه نسخه رفتار سازمانى مثبت مطرح مىشود، اعتماد به نفس (خودكارامدى)،

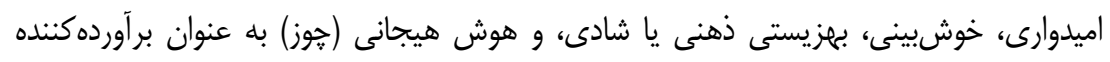

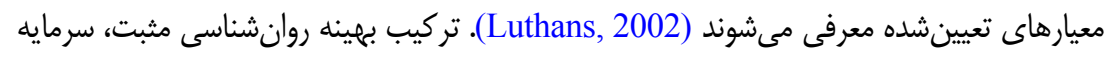
انسانى، و سرمايه اجتماعى راضرورت اجتنابنايذير براى شكلدهى رئ رفتارهاى سازمانى مثبت مى دانند:
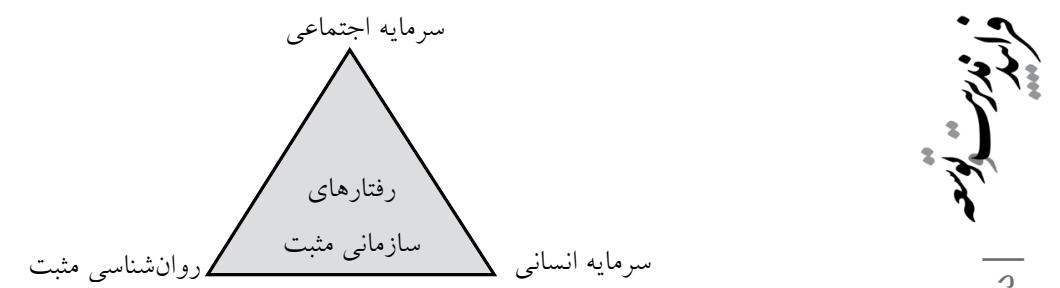

شكل 1: عوامل تشكيلدهنده رفتارهاى سازمانى مثبت (شيروانى و سىسختى، ||1\%)

معيارهاى زير از جمله سازهاى تعيين كننده در تعريف رفتار سازمانى مثبت هستند: الف. بر بايه

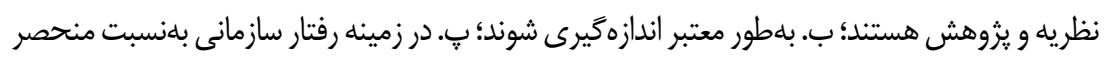

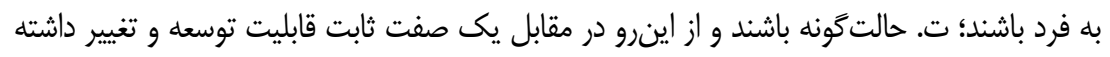

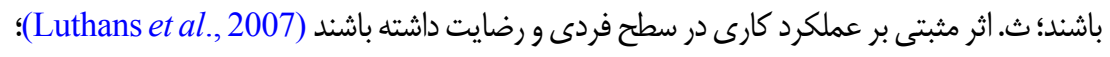

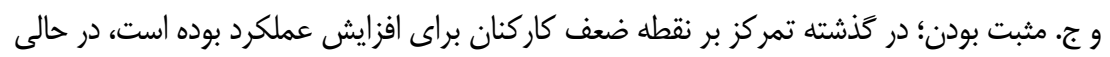
بايد بر جنبههاى مثبت عملكرد فردى تمركز كرد (Geiman, 2016).

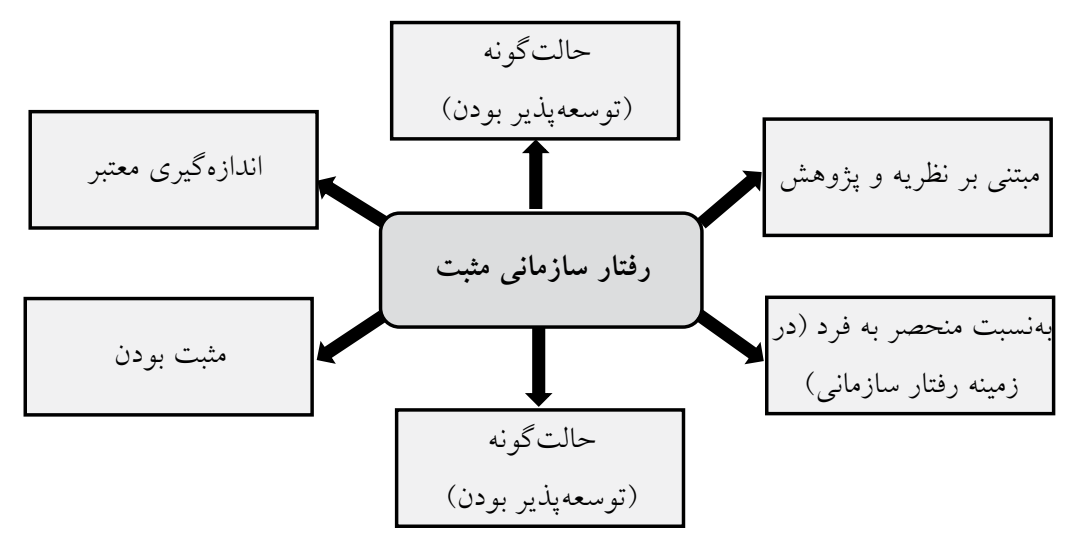

شكل ז: معيارهاى لازم براى تشخيص متغيرهاى رفتار سازمانى مثبت 
لوتانز (ץ +.r)، سطوح تحليل مثبت كرايى را به اين شح اشاره مى كند: در سطح ذهنى (يعنى تجارب ذهنى مثبت مانند بهزيستى و رضايت نسبت به كذشته، غرقه شدن و شادى در حال، و اميدوارى

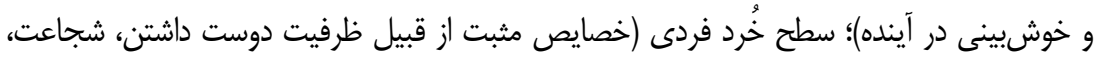

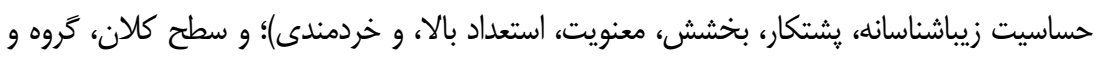

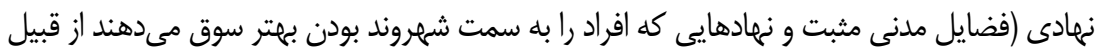
مسئوليتيذيرى، نوعدوستى، نزاكت، اعتدال، تحمل و اخلاق كارى قوى) (Luthans, 2002). لوتانز

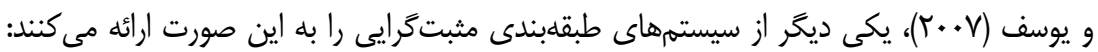

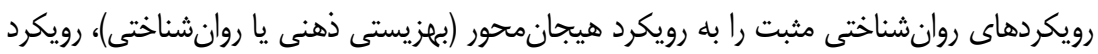

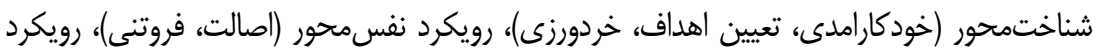
بينفردى (بخشش، قدردانى، دلسوزى)، رويكرد زيستى (جقرى و سفتى)، و رويكردهاى مقابله

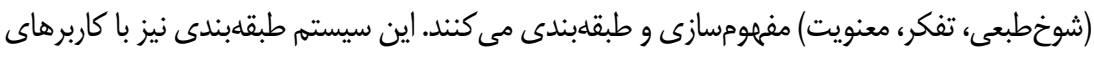

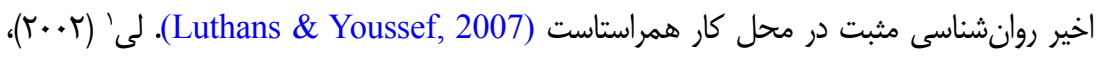

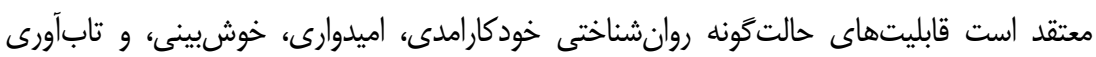

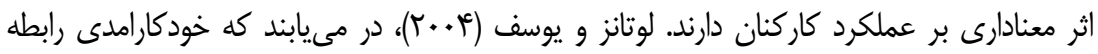

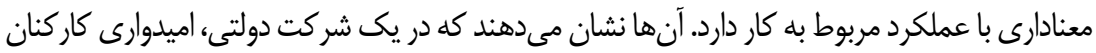

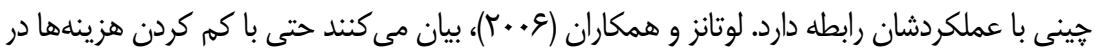

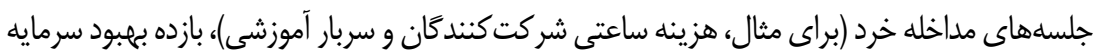

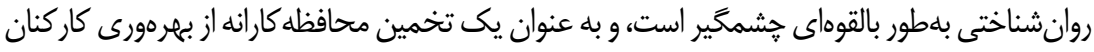

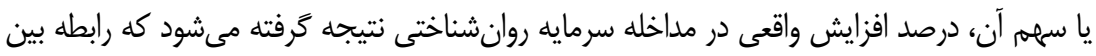

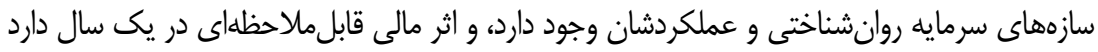

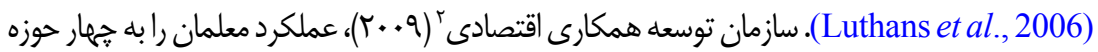
عمده تقسيم مى كند: برنامهريزى و آمادهسازى شامل ارائه دانش محتواى آموزشى و فن تعليم و تربيت،

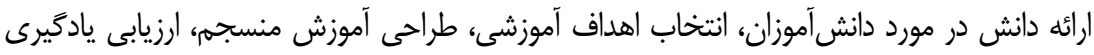

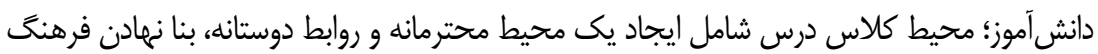
يادگيرى، مديريت رويههاى كلاس درس، مديريت رفتار دانشآموز و سازماندهى فضاى فيزيكى؛

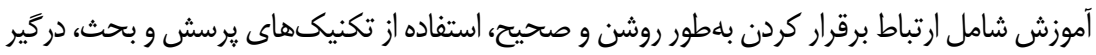

1. $\mathrm{Li}$

2. Organization for Economic Co-operation and Development (OECD) 
كردن دانشآمزان در يادكيرى، فراهم كردن بازخورد به دانشآموزان، انعطاف و مسئوليتيذيرى؛ و مسئوليتهاى حرفهاى شامل تامل در تدريس، حفظ درست سوابق، برقرارى ارتباط با خانوادهها، مشاركت فرانت با مدرسه و بخش، رشد و توسعه حرفهاى، و نشان دادن حرفهاى بودن (OECD, 2009).

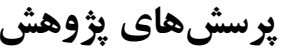

ا. مدل بهرهورى معلمان با رويكرد رفتار سازمانى مثبت هيست؟

r. متغيرهاى درونداد' مدل بهرهورى معلمان با رويكرد رفتار سازمانى مثبت كداماند؟ باني ץ. فرايندهاى ياددهى ـ يادكيرى 'مدل بهرهورى معلمان با رويكرد رفتار سازمانى مثبت كداماند؟

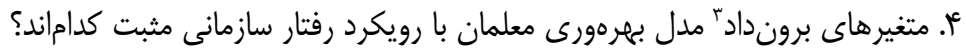

\section{روش اشناسى ثزوهش}

يزوهش حاضر بر مبناى هدف از نوع كاربردى و از نظر روش، آميخته است. بدين معنا كه در مرحله

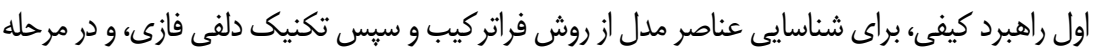

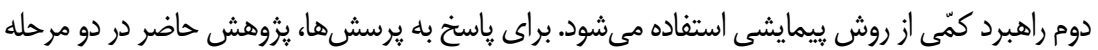
ياييرزيزى مىشود؛ در مرحله اول يزوهشكران با استفاده از روش كيفى فراتركيب" مقولهها (ابعاد)، مفاهيم

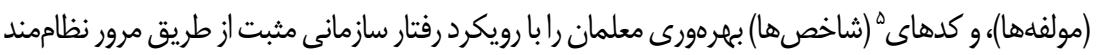

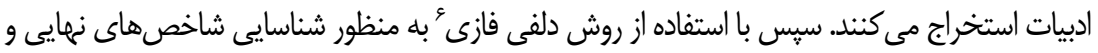

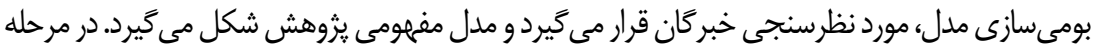

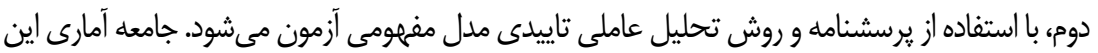

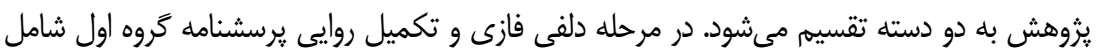

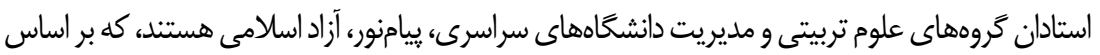

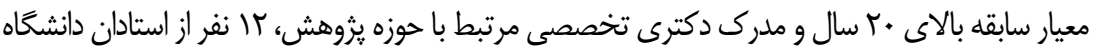

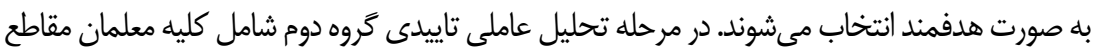
1. Input
2. Teaching - Learning
3. Output
4. Meta-Synthesis
5. Codes
6. Fuzzy Delphi 
ابتدايى و متوسطه مدارس كل كشور (وزارت آموزش و يرورش، \هسا)' به تعداد هو نفر تعيين

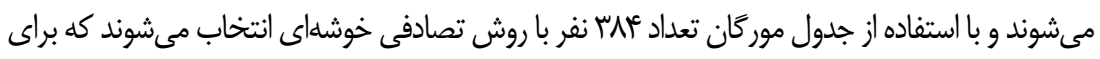

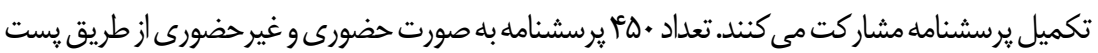

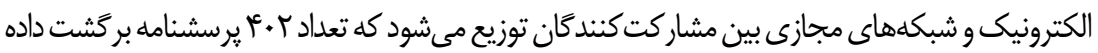

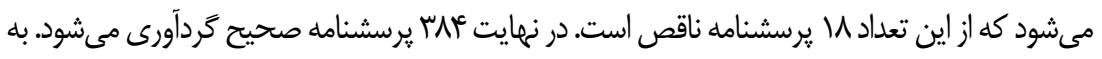
منظور كاهش خطاى سوگيرى، يرسشنامهها در ينج نقطة كشور بين معلمان استانهاى تهران، خراسان رضوى، مازندران، هرمزًان، و كرمانشاه به نسبت جمعيت استان ها، جنسيت، و مقطع تدريس توزيع مى بـود.

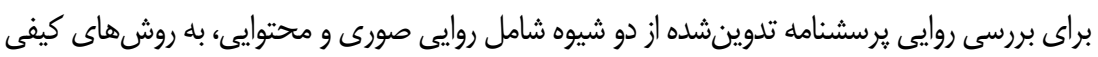

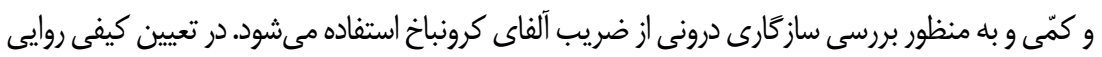

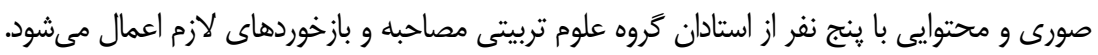
يرسشنامه اصلاحشده براى تعيين روايى صورى و محتوايى كمّى در اختيار ها نفر از متخصصان قرار داده

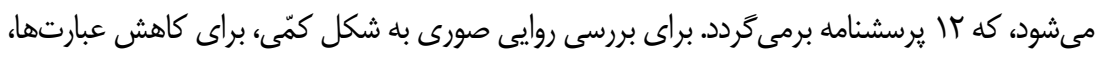

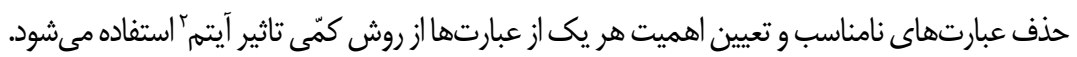

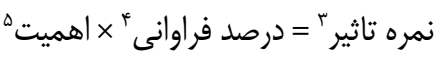

در روش تاثير آيتم، در صورتى كه نمره تاثير مساوى يا بيشتر از ه/ إشد، براى تحليلهاى بعدى مناسب تشخيص داده مىشود (حسينى و همكاران، سوس|). نمره تاثير همه گَويهها بيشتر ئر

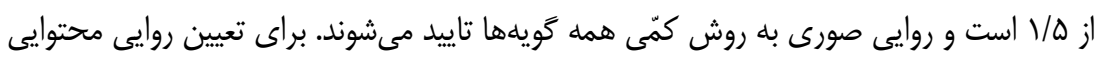

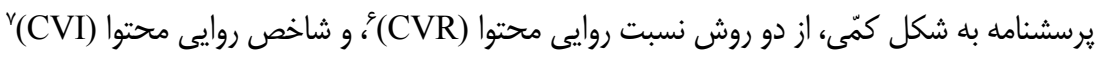

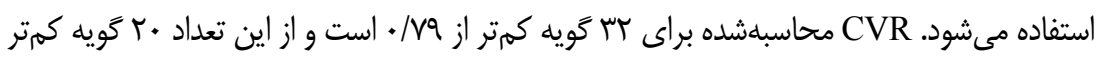

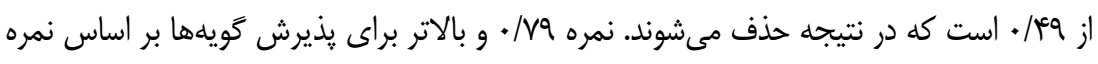
CVI

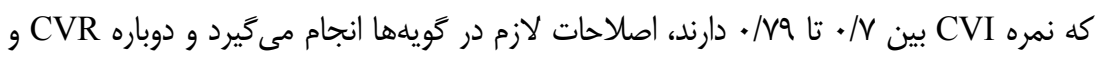
CVI

1. https://www.medu.ir

2. Item Impact Method

3. Impact Score

4. Frequency

5. Importance

6. Content Validity Ratio

7. Content Validity Index 
9 • و بالاتر براى يذيرش S-CVI/Ave توصيه مىشود كه براى اين يرسشنامه مقدار آن (9/• است كه نشاندهنده كافى بودن روايى محتوايى يرسشنامه است. براى تعيين یايايى يرسشنامه اصلاحشده

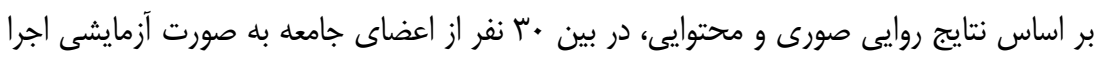

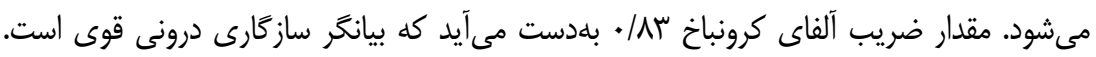

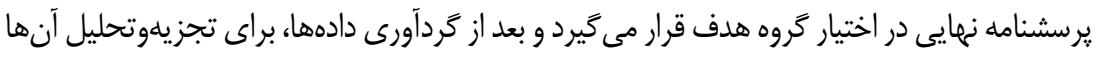
از نرم|فزارهاى LISREL 8.8 و 26 SPSS استفاده مىشود.

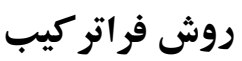

هدف روش فراتركيب ايجاد تفسير يكيارجه و جديدى از يافتهاست (جعفرى و همكاران، هوسا). از آنجا كه مفهوم بهرهورى معلمان با رويكرد رفتار سازمانى مثبت مفهومى هندبعدى و

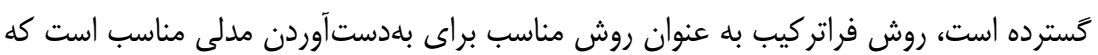
از تلفيق مدلهاى ارائهشده در اين حوزه، بر يايه تفسير آنهاست. هدف از اين فرايند يوشش نقاط ضعف مدلهاى مختلف با نقاط قوت ساير مدلها و ترميم كاستى هاى مدل جديد است، مدلى كه با شرايط و مقتضيات معلمان شاغل در وزارت آموزش و يرورش متناسب و سازگار باشد.

\section{كامها و روش كار در فراتركيب}

در يزوهش حاضر به منظور تجزيلوتحليل دادههاى استخراجى از ادبيات يزوهش از روش هفتمرحلهاى استفاده مىشود.

\section{كَام نخست: تنظيم يرسش يزوهش}

در اين يزوهش براى تنظيم يرسش ثيزوهش مراحل زير طى مىشود:

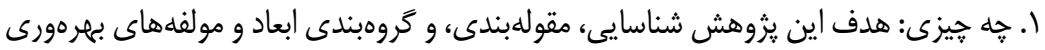

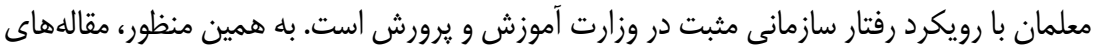

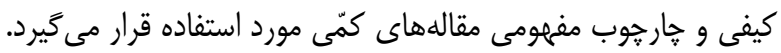

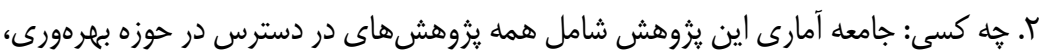
عملكرد معلمان، و رفتار سازمانى مثبت است كه از محل يايگاههاى اطلاعاتى تامين مىشود. r. جه وقت: محدوه زمانى منابع يافتشده شامل مقالههاى انخليسى مطالعهشده از سالهاى

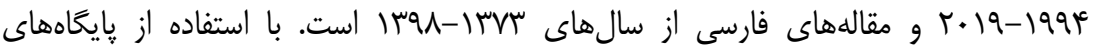
اطلاعاتى، براى وازه 》رفتار سازمانى مثبته مقاله انحليسى مربوط به رفتار سازمانى مثبت ييش از 


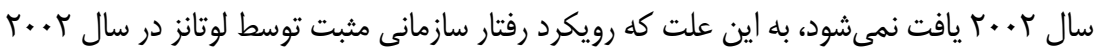

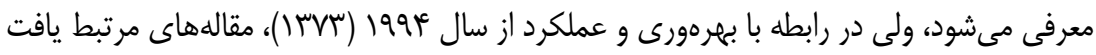

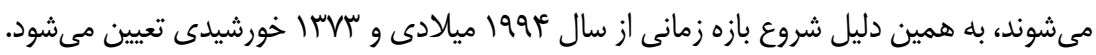

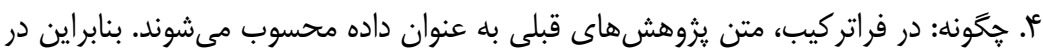

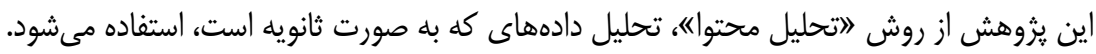

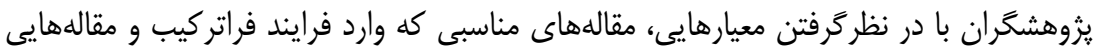
كه از فرايند خارج مىشوند، شناسايى مى بن

\section{كَام دوم: بررسى متون به صورت نظاممند}

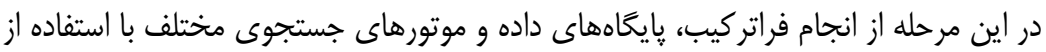
كليدوازههاى مندرج در جدول (ץ) براى جستجوى مقالهها استفاده مى شوند. كَام سوم: جستجو و انتخاب مقالههاى مناسب

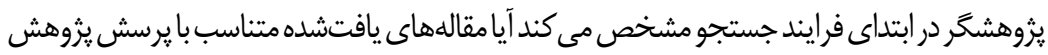
است يا خير؟ به منظور رسيدن به اين هدف، معيارهايى براى يذيرش يا رد در نظر گرفته مىشود و بر اساس

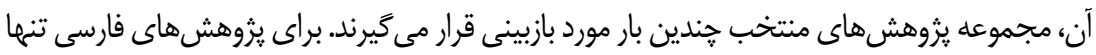

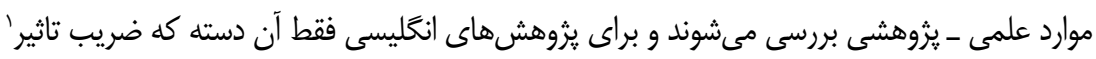

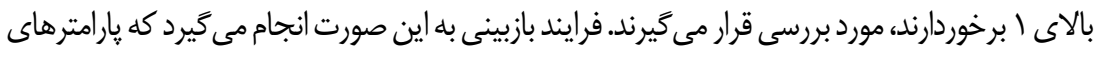

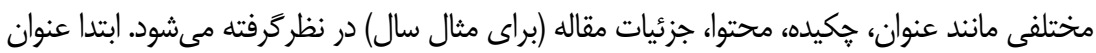

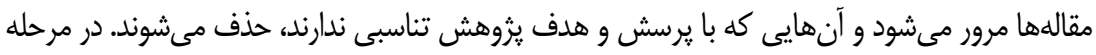

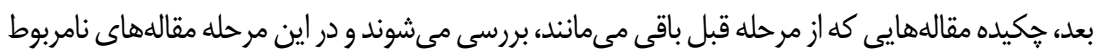

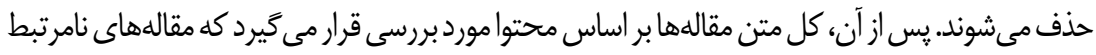

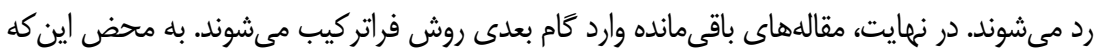
مقالهها به منظور تناسب با بارامترهاى يثرهش بررسى مىشود، در كام بعدى بايد كيفيت روش شناختى

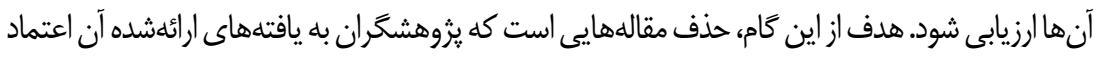

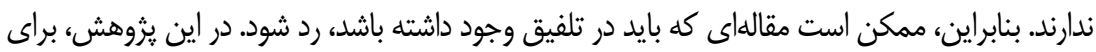

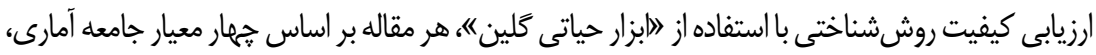

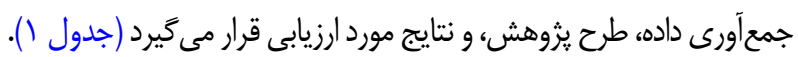




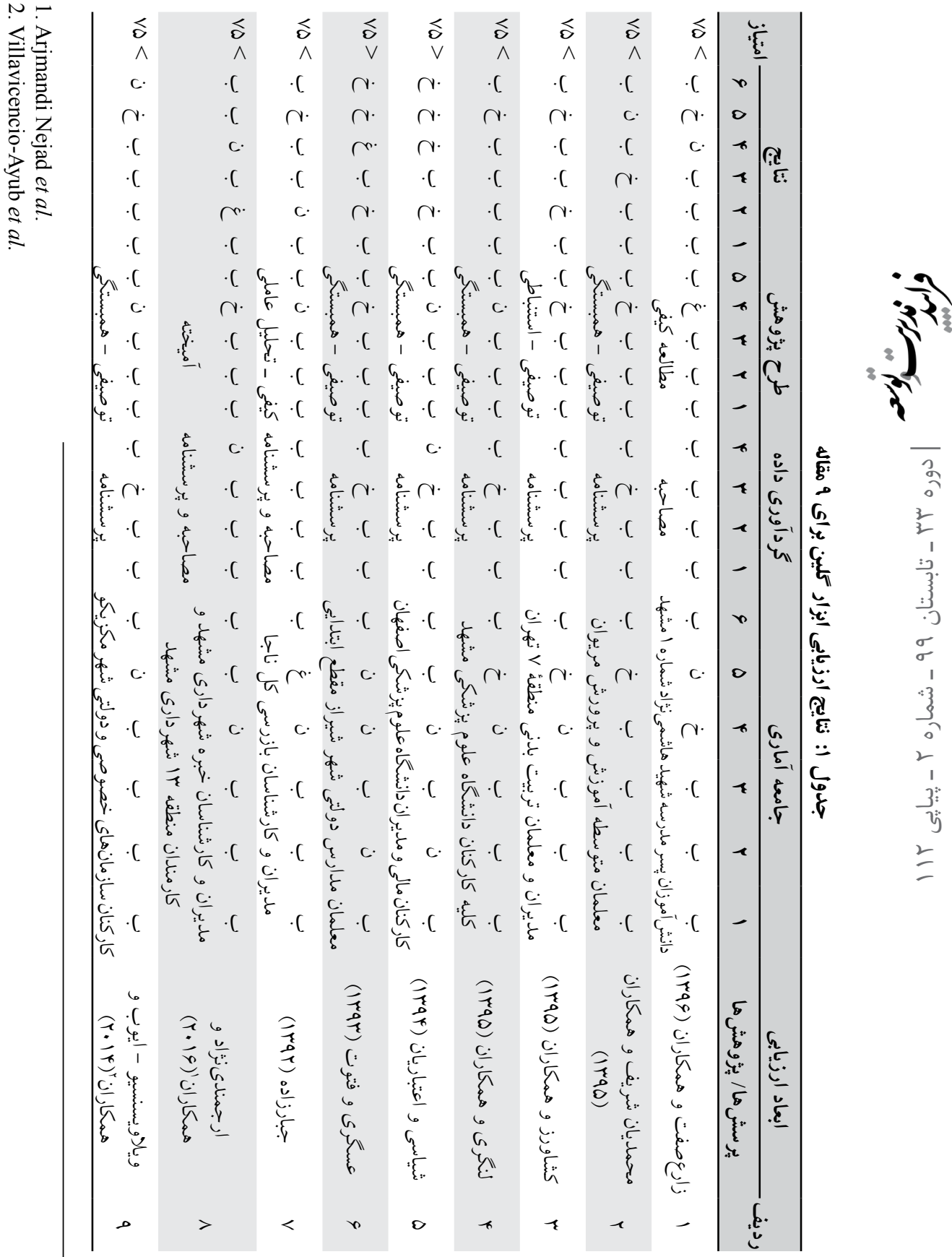




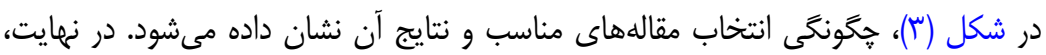

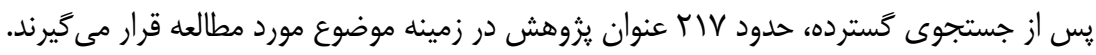

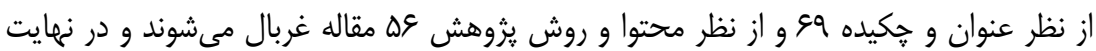
rو يثوهش براى انجام فراتر كيب بهدست مى آيد.

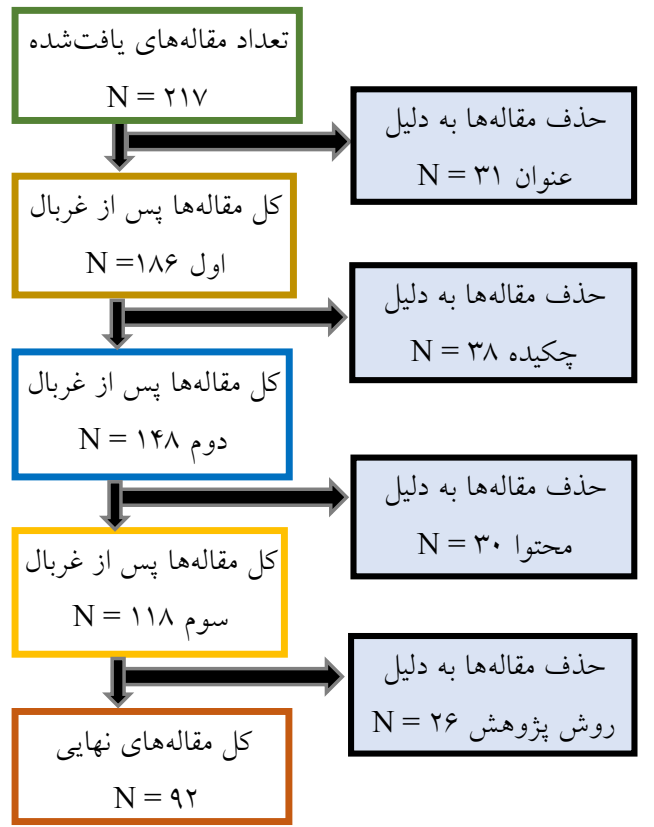

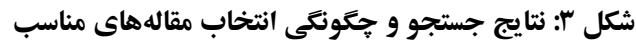




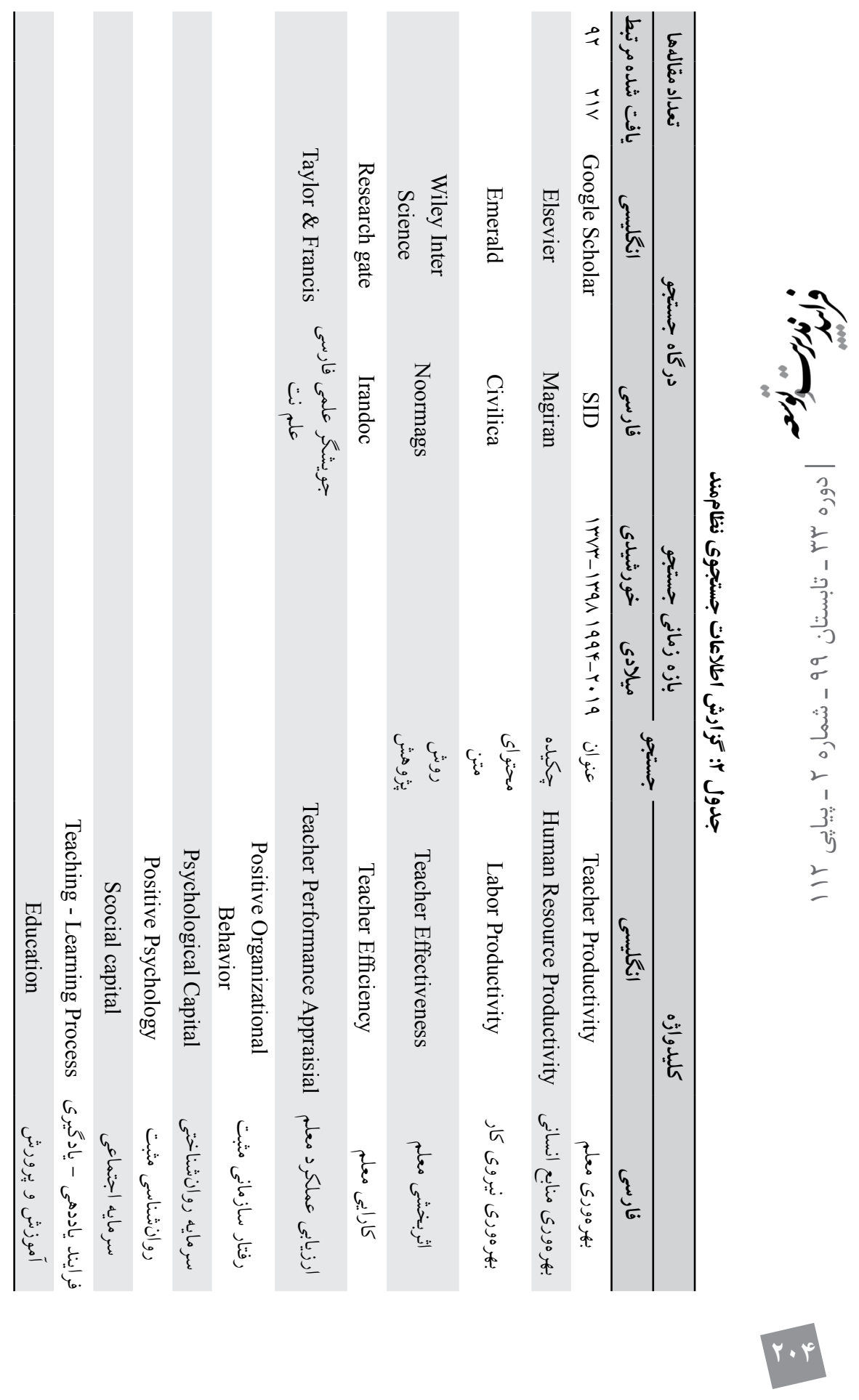




\section{كام جهمارم: استخراج نتايج}

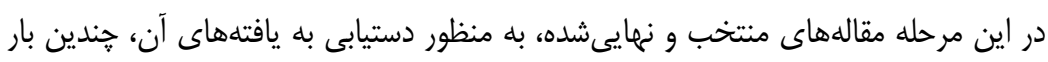
بازخوانى مىشوند و در ستونهاى جداًانهاى شامل نام و نام خانوادگى نويسنده به همراه سال

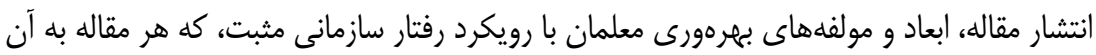

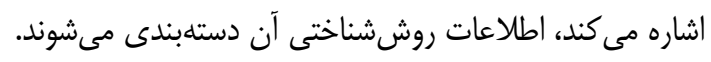

\section{كام ينجم: تجزيهوتحليل و تلفيق يافتههاى كيفى}

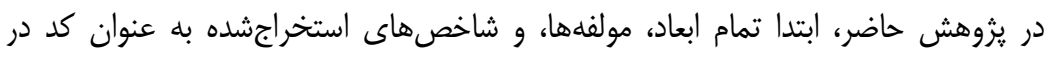

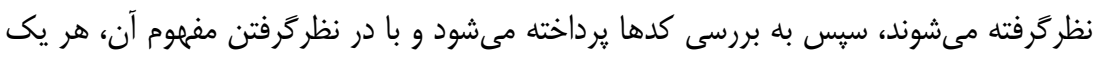

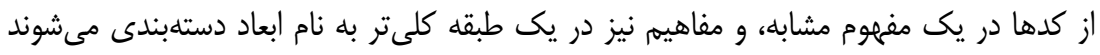

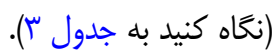




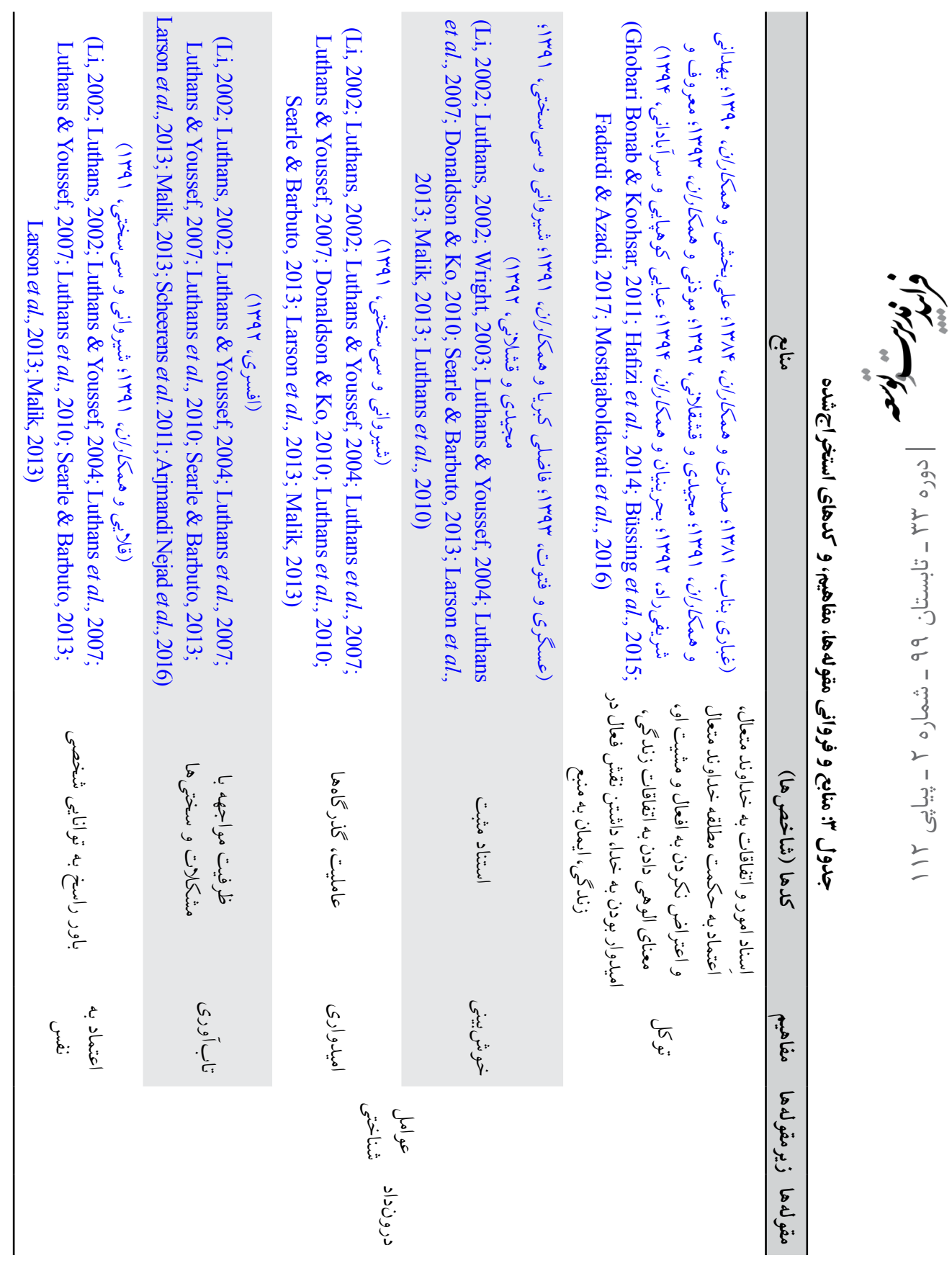




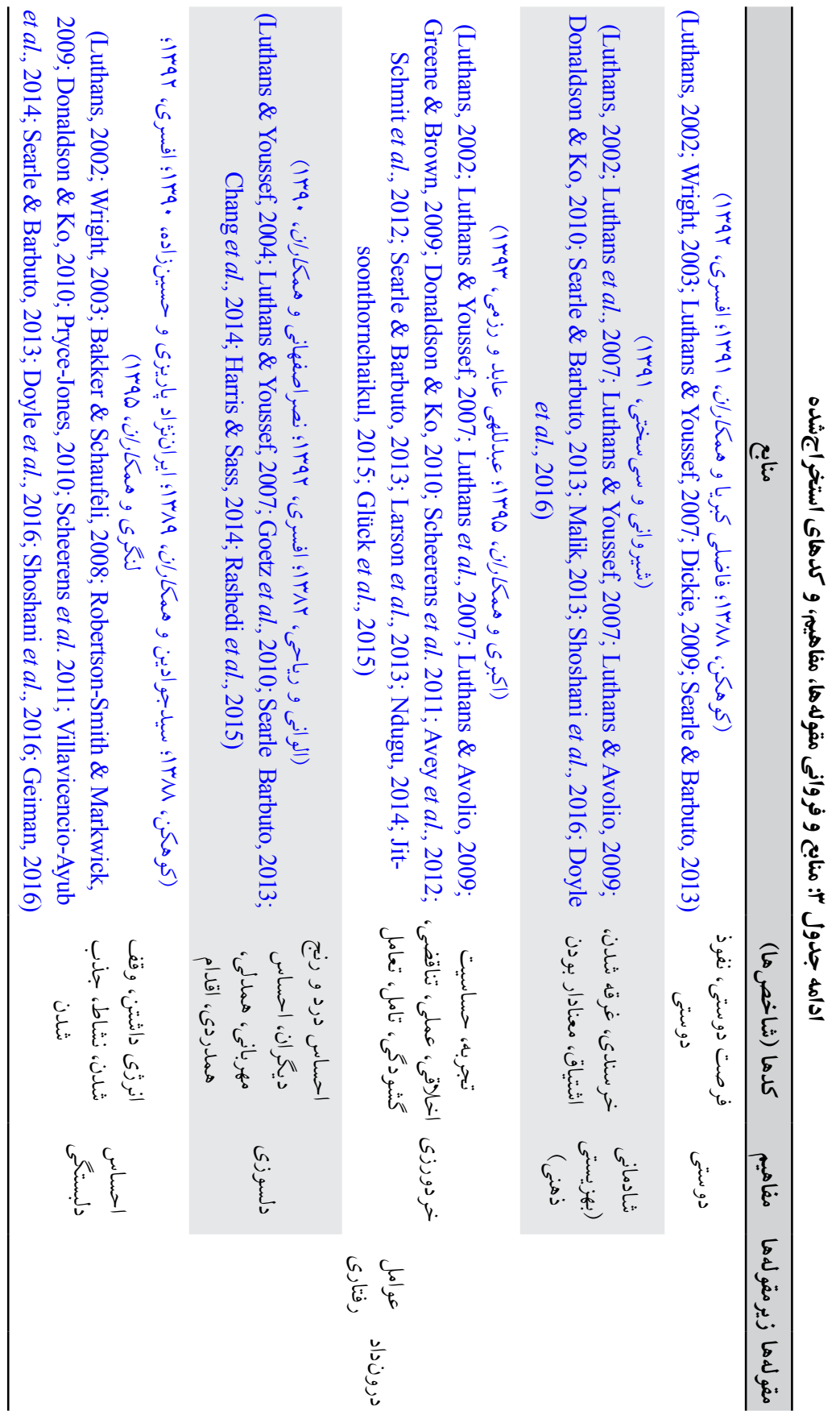




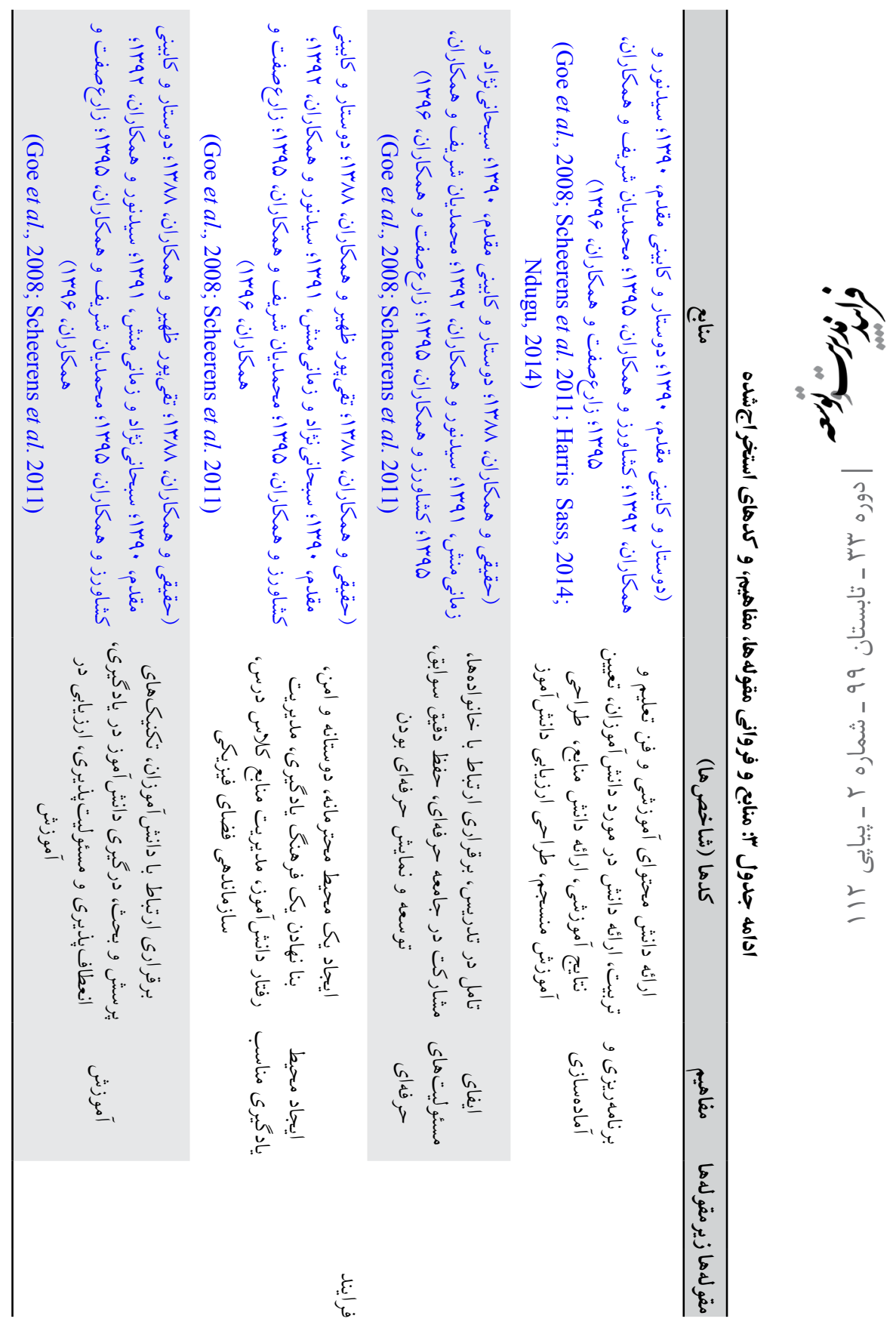




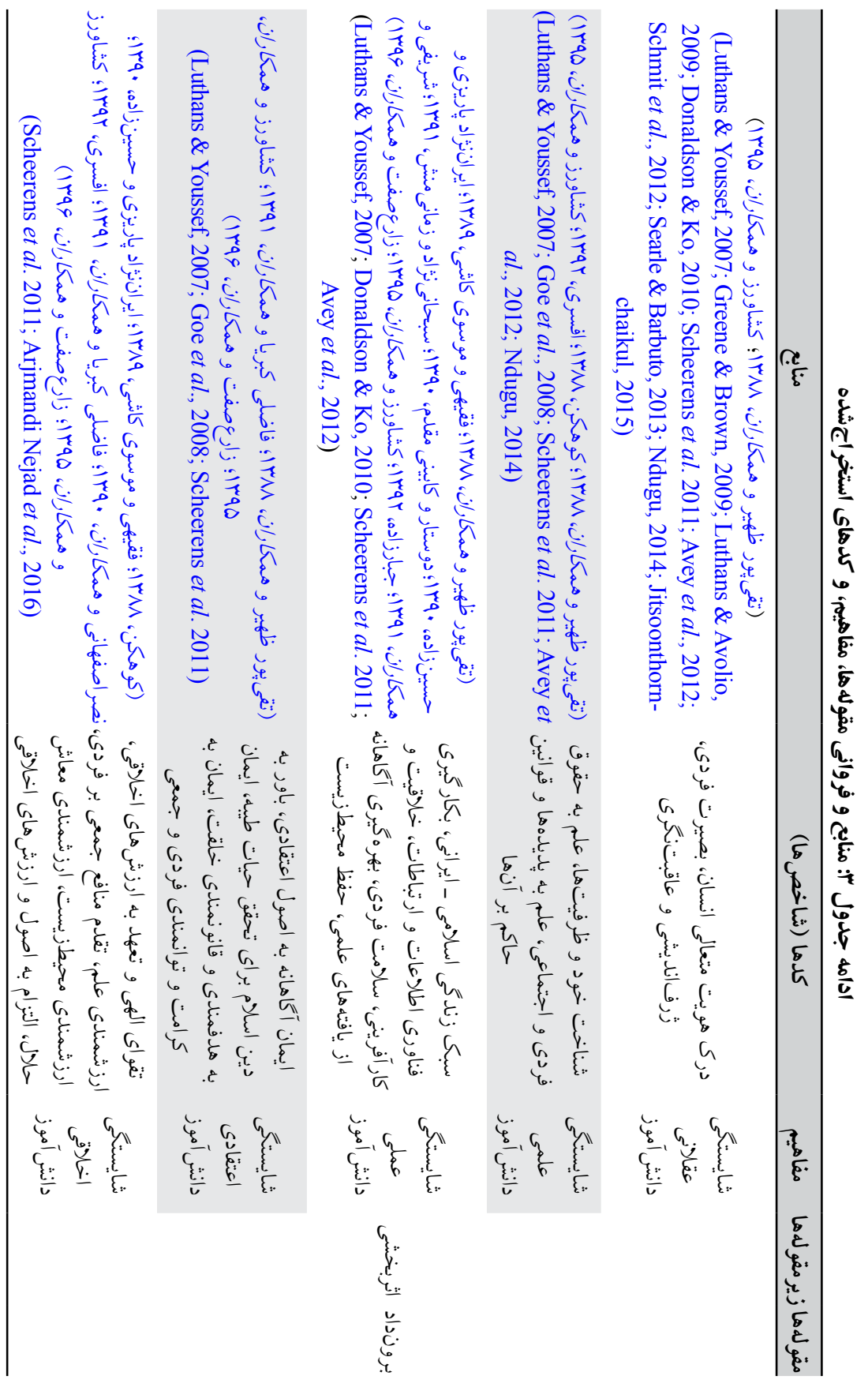




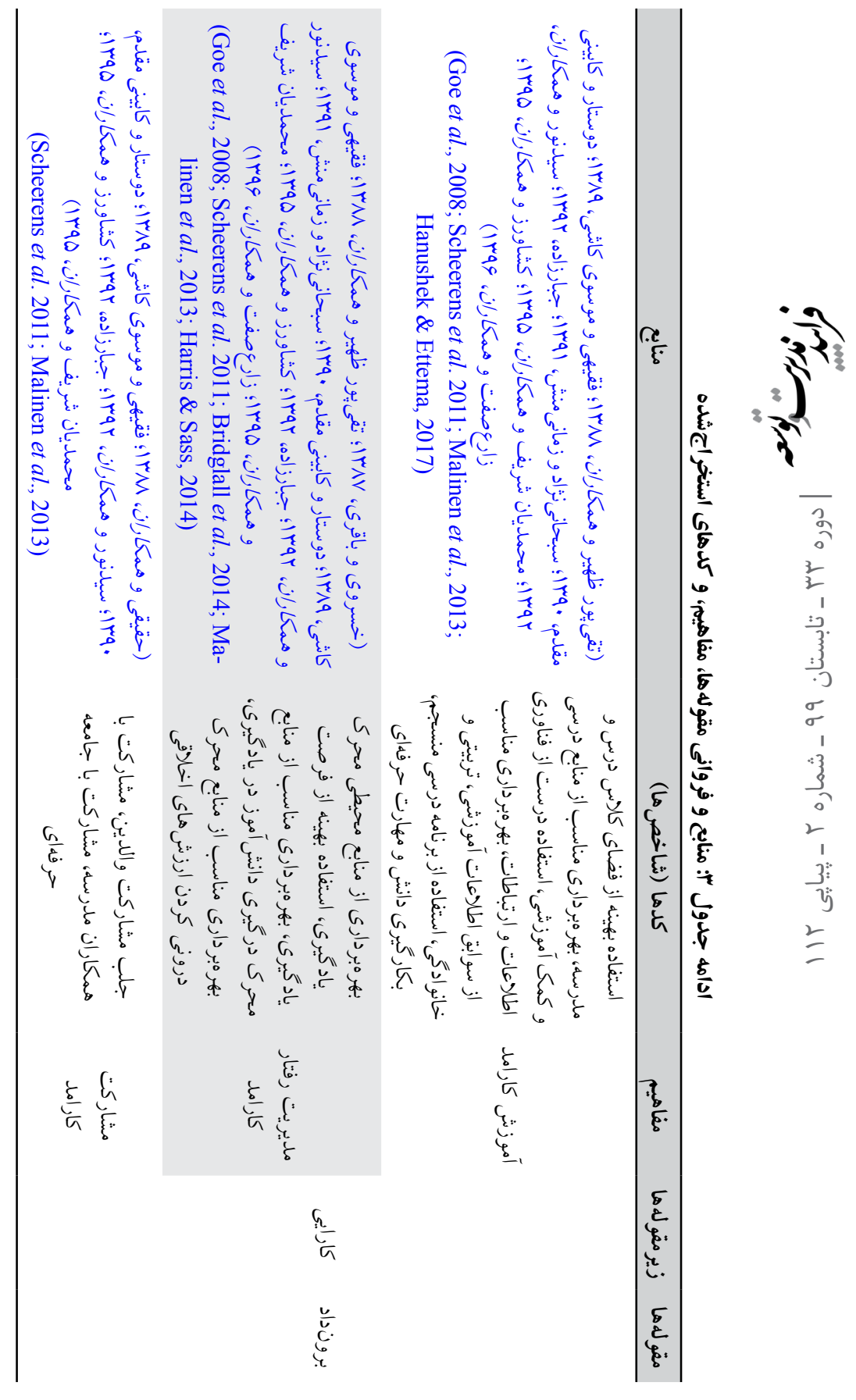


كام شثم: حفظ كنتر ل كيفيت

براى دستيابى به اين هدف، تعدادى از مقالههاى انتخابى در اختيار يكى از خبركان قرار مى گيردو نتايج

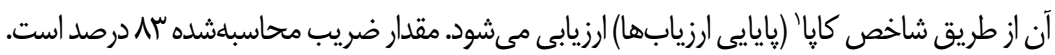

\section{ارائه يافتههاى فراتر كيب}

در اين مرحله از يخوهش، با استفاده از روش فراتر كيب س مقوله (بُعد)؛ أ زيرمقوله؛ با مفهوم

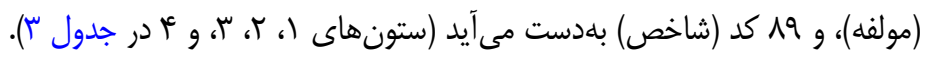

\section{مرحله دوم: روش دلفى فازى}

در اين بخش، براى غربال شاخصها و شناسايى شاخصهاى نهايى از رويكرد دلفى فازى استفاده

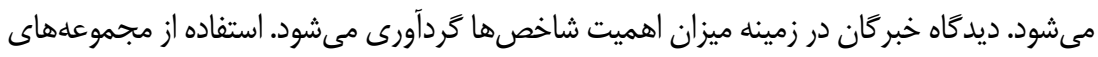

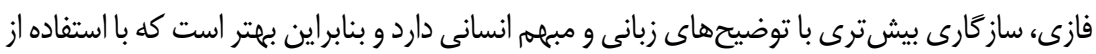

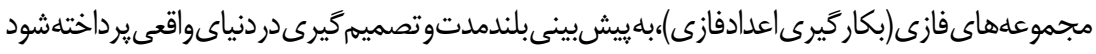
(Kahraman, 2009). در اين يزوهش، براى فازى سازى ديدكاه خبر كان از اعداد فازى مثلثى استفادهاه

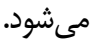

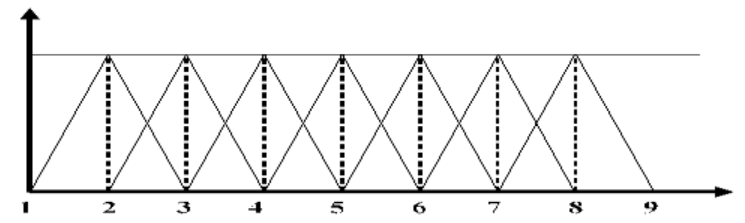

شكل † : ارزش كذارى شاخصها نسبت به هم با استفاده از اعداد فازى مثلثى

جدول †: طيف نُهدرجه فازى براى ارزشعذارى شاخصها

\begin{tabular}{|c|c|c|}
\hline مقياس عدد فازى & متغير زبانى & معادل قطعى \\
\hline$(1,1,1)$ & خيلى بىاهميت & 1 \\
\hline$(1, r, r)$ & خيلى بى اهميت تا بى اهميت & r \\
\hline$(Y, r, r)$ & بى اهميت & r \\
\hline 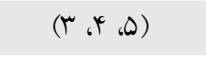 & بىاهميت تا اهميت متوسط & r \\
\hline$\left(\begin{array}{l}\uparrow \\
\uparrow\end{array}, 9\right)$ & متوسط & 0 \\
\hline$(\Delta, G, V)$ & متوسط تا با اهميت & 4 \\
\hline
\end{tabular}

1. Kappa 
ادامه جدول ^: طيف نُهدرجه فازى براى ارزشكذارى شاخصها

\begin{tabular}{|c|c|c|}
\hline مقياس عدد فازى & متغير زبانى & معادل قطعى \\
\hline$(9, \vee \mathcal{N})$ & با اهميت & v \\
\hline$(\vee \triangleleft \wedge, 9)$ & با اهميت تا خيلى با اهميت & $\wedge$ \\
\hline$(9.91)$ & خيلى با اهميت & 9 \\
\hline
\end{tabular}

فازىسازى ديدكاه خبر كان ييرامون هر شاخص در جدول (ه) نمايش داده مىشود:

جدول ه: فازىسازى ديد كاه ينل خبر كان براى هر يك از شاخصها

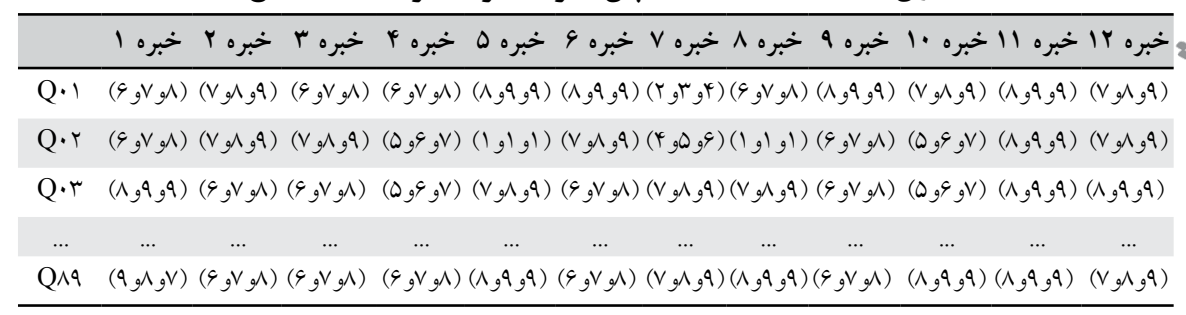

\section{يافتهاى روش دلفى فازى}

ميانكَين فازى و برونداد فازىزدايى' شده مقادير مربوط به شاخصها در جدول (و) كزارش

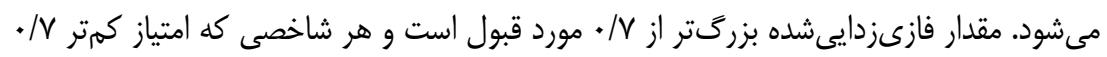
داشته باشد، رد مىشود (Wu \& Fang, 2011).

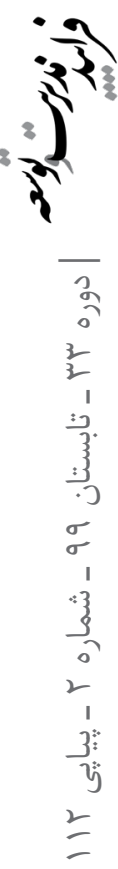

جدول \&: ميانكين فازى و غربالكرى فازى شاخصها (كام اول)

\begin{tabular}{|c|c|c|c|c|c|c|}
\hline كام اول & كران بالا & محتمل ترين مقدار & كران يُايين & ميانغين & قطعى & نتايج \\
\hline Q1 & $9 / 01$ & $\mathrm{~V} / \mathrm{Q \Lambda}$ & $\Lambda, \Gamma Q$ & $(\Lambda / T \Delta, V / \Delta \Lambda, G / \Delta \Lambda)$ & $V / A V$ & يذيرش \\
\hline$Q^{r}$ & $Q / I V$ & $9 / \cdots$ & GNQ & $(9 / N \Delta, 9 / 0, Q / I V)$ & $Q / 9 V$ & رد \\
\hline Qr & $9 / 0$ & $\mathrm{~V} / \mathrm{Q}$ & $\Lambda / T Q$ & $(\Lambda / T \Delta, V / \Delta, G / \Delta)$ & V/AT & يذ \\
\hline$\ldots$ & $\ldots$ & $\ldots$ & $\ldots$ & $\ldots$ & $\ldots$ & $\ldots$ \\
\hline$Q \wedge 9$ & q/VQ & $\mathrm{V} / \mathrm{VQ}$ & N/KT & $(\Lambda / K T, V / V Q, G / V Q)$ & $\mathrm{V} / 9 \mathrm{Y}$ & يذ بذيرش \\
\hline
\end{tabular}

1. Defuzzification

2. Crisp 
كام اول: تمامى مواردى كه امتيازى كمتر از / • كسب مى كنند، حذف مى شوند. شاخصهاى

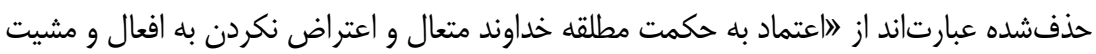

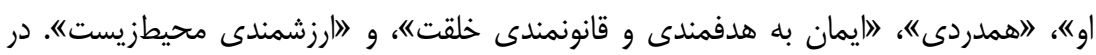

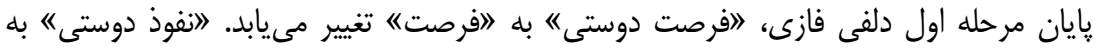

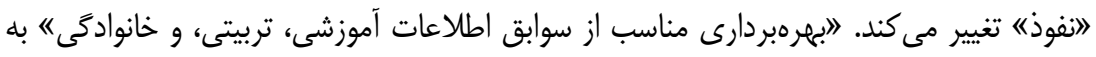

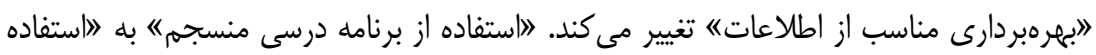

$$
\text { از طرح درس منسجمه تغيير مى كند. }
$$

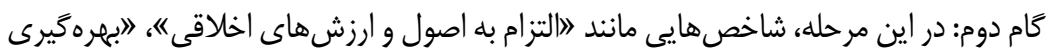

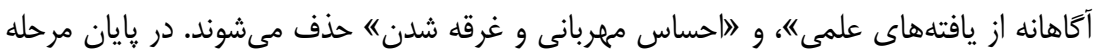

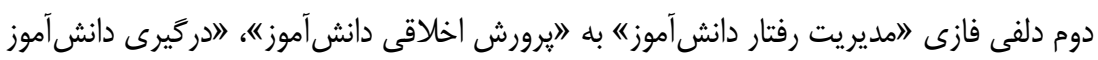

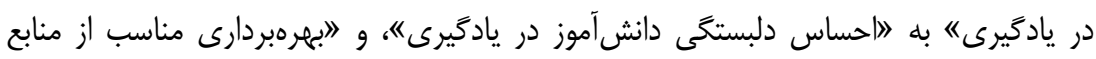

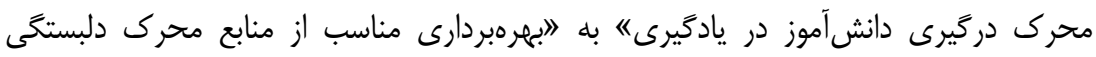
دانش آموز در يادَّيرى" تغيير مى ديابد.

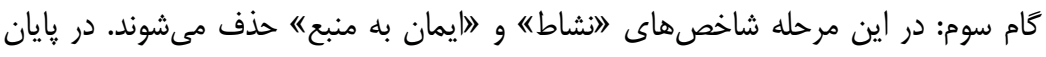
اين مرحله (ايجاد يك محيط محترمانه، دوستانه و امن"، لايجاد يك محيط عادلانه، محترمانه،

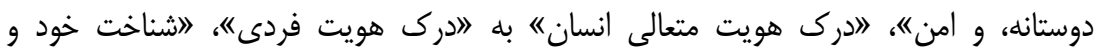

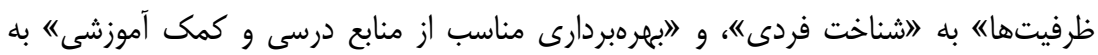
"ابهرهبردارى مناسب از منابع درسى و كمى درسى" تغيير مى كند. 


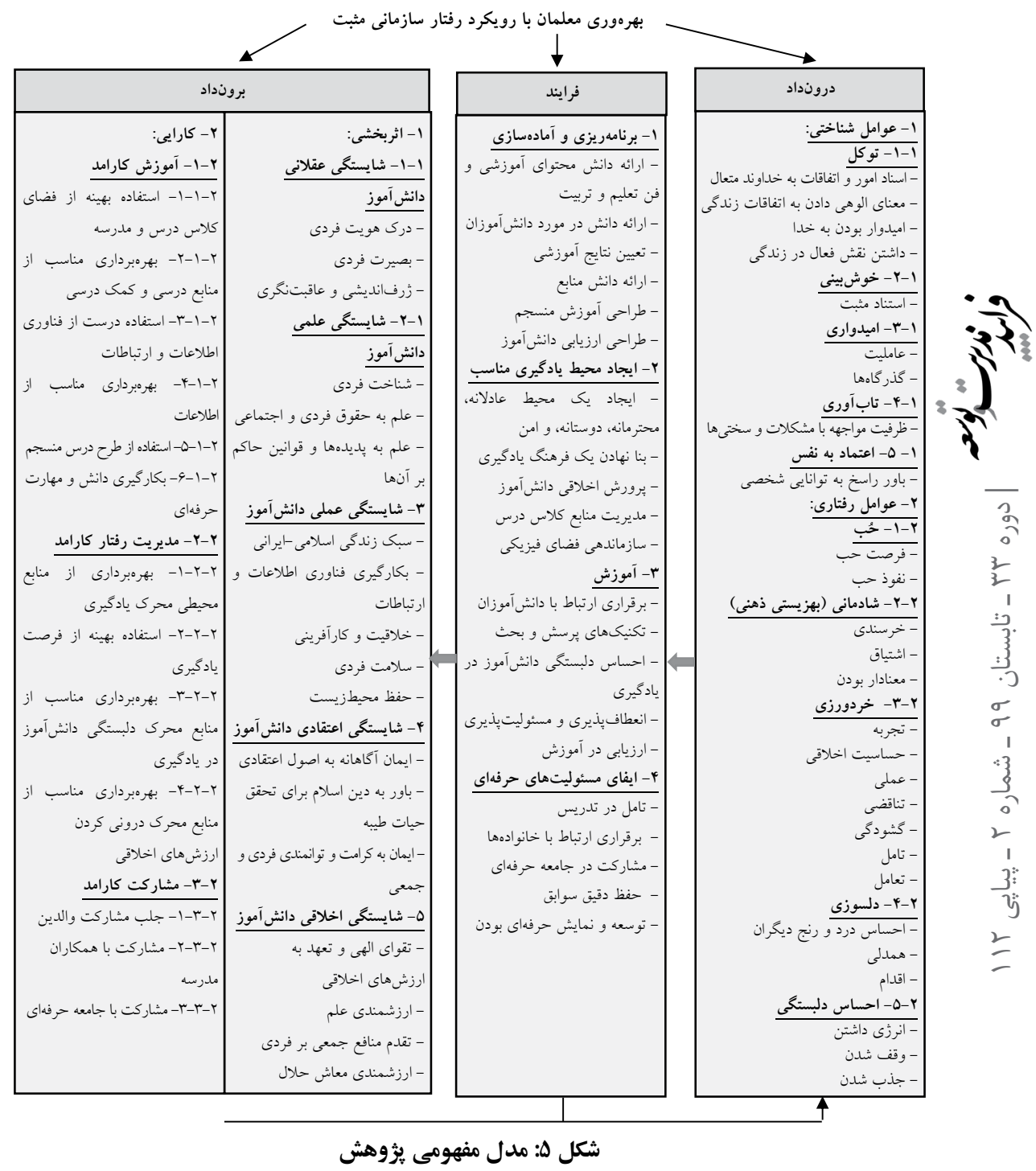




\section{مرحله دوم: تحليل عاملى تاييدى}

در اين بخش، براى سنجش متغيرهاى يزوهش از ابزار يرسشنامه و از تحليل عاملى تاييدى

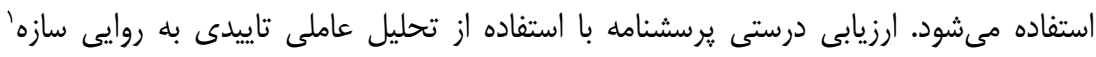

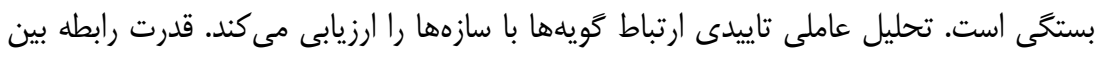

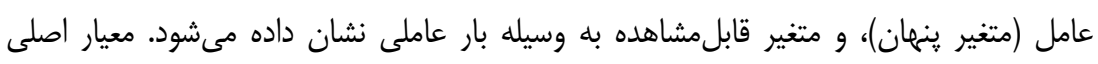

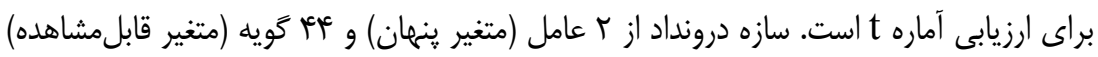

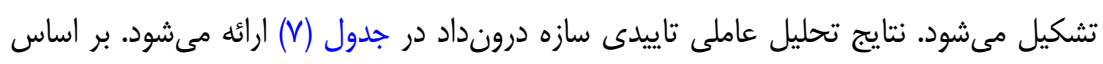

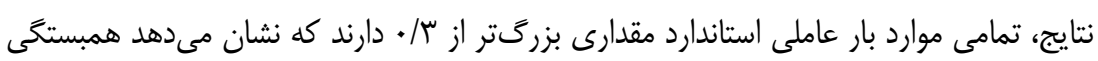

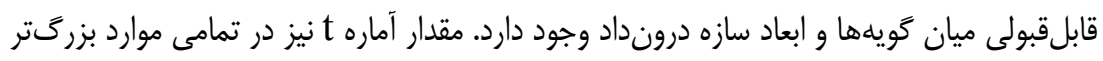

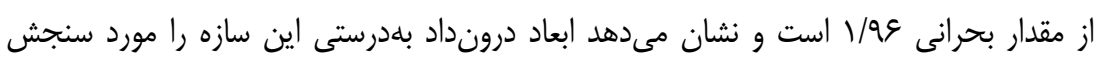

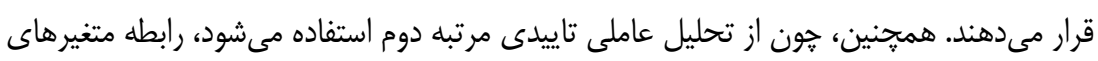

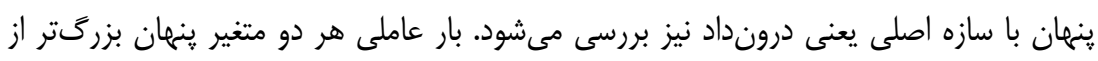

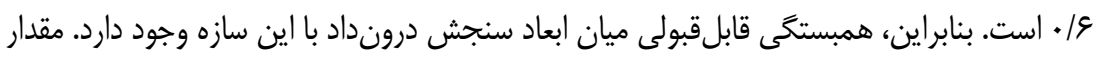

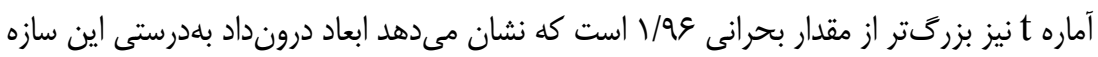

$$
\text { را مورد سنجش قرار مىدهند. }
$$

جدول Y: خلاصه نتايج تحليل عاملى تاييدى مرتبه دوم سازه درونداد و شاخصهاى برازش نعاد

\begin{tabular}{|c|c|c|c|c|c|c|c|}
\hline RMSEA & $\frac{\chi^{2}}{\mathbf{d f}}$ & آماره آزمون & بازهٔ بارهاى عاملى & شرسماره & تعديه هاد & متغيرهاى ينهان & سلى سازه \\
\hline \multirow{2}{*}{.1 .49} & \multirow{2}{*}{$1 / 94$} & $N / 41-1 \cdot / N V$ & $\cdot / 9 \mu_{-} \cdot / 9 \mu$ & $1 \cdot 1-111$ & 11 & عوامل : & \multirow{2}{*}{ درونداد } \\
\hline & & $1 / \uparrow q-q / 1 V$ & $\cdot / 9 \mathrm{~V}-\cdot / \mathrm{Al}$ & $119-144$ & TQ & عو امل رفتارى & \\
\hline
\end{tabular}

شاخص برازش RSMEA برابر و\&+/ است. مقدار خى - دو بهنجار (خى - دو تقسيم بر

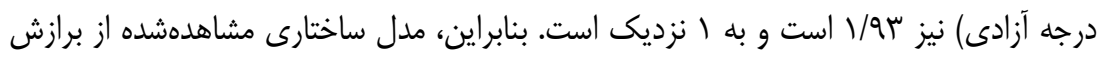

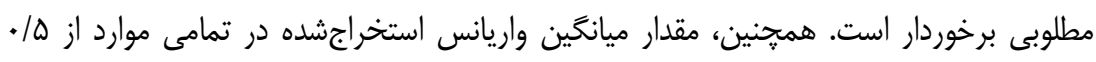

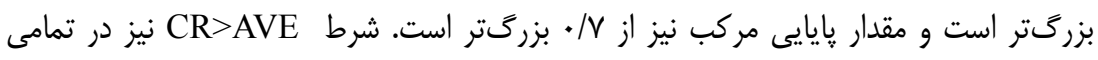
موارد برقرار است.

1. Construct Validity 


\section{يافتههاى تحليل عاملى تاييدى سازه فرايند}

سازه فرايند از جهار متغير ينهان برنامهريزى و آمادهسازى، ايجاد محيط يادَّيرى مناسب،

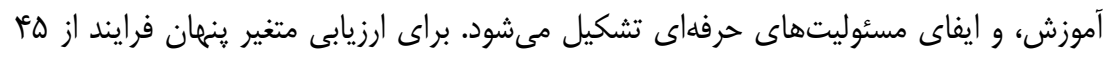

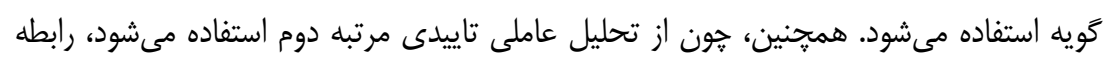

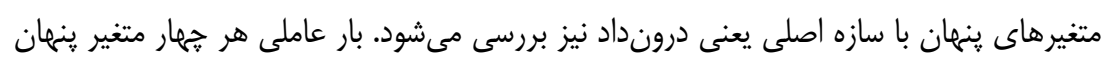

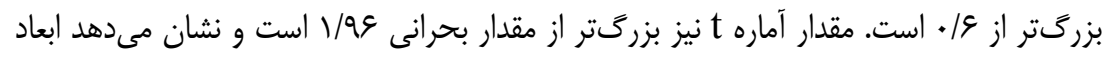

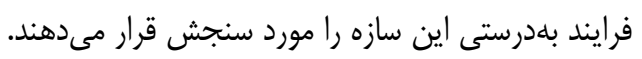

جدول ^: خلاصه نتايج تحليل عاملى تاييدى مرتبه دوم سازه فرايند و شاخصهاى برازش

\begin{tabular}{|c|c|c|c|c|c|c|c|}
\hline RMSEA & $\frac{\chi^{2}}{\mathrm{df}}$ & آماره آزمون & بازه بارهاى عاملى & برسماره & تعويهها & متغير هاى ينهان & سلم \\
\hline \multirow{4}{*}{$\cdot / \cdot Y T$} & \multirow{4}{*}{$1 / N r$} & $\Lambda / q q-\psi / 4 \Delta Q$ & $\cdot / 99-\cdot / 11$ & $1-11$ & Ir & بر بامهريزى و & \multirow{4}{*}{ فرايند } \\
\hline & & $9 / V 9-9 / 9 T$ & $\cdot / 9 \Lambda-\cdot / \Lambda r$ & $\mid r-r Q$ & Ir & ايجاد محيط يادكيرى & \\
\hline & & $V / \cdots-q / T 4$ & $\cdot / 9 \mathrm{~V}-\cdot / 1 \mathrm{D}$ & rG-ro & 1. & آموزش & \\
\hline & & $V / \mu{ }^{c}-q / T_{1}$ & $\cdot / V Y-\cdot / A Y$ & ra-ky & 1. & ايفاى مسئوليتهاى & \\
\hline
\end{tabular}

شاخص برازش RSMEA برابر rא./• است. مقدار خى - دو بهنجار (خى - دو تقسيم بر

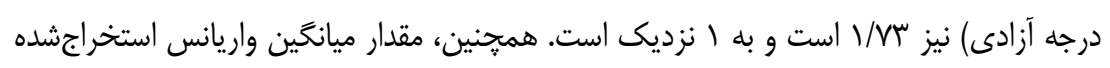

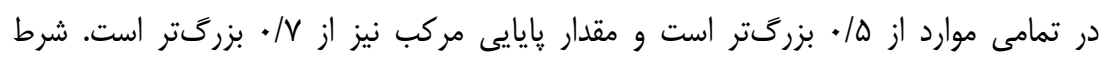
نR>AVE

\section{يافتهاى تحليل عاملى تاييدى سازه برونداد}

سازه برونداد از دو متغير ينهان اثربخشى و كارايى تشكيل مىشود. براى ارزيابى متغير ينهان

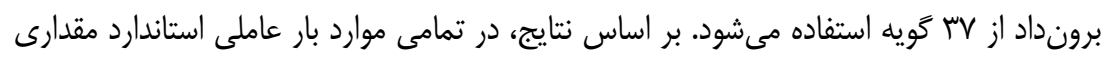

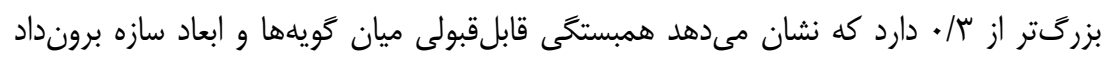

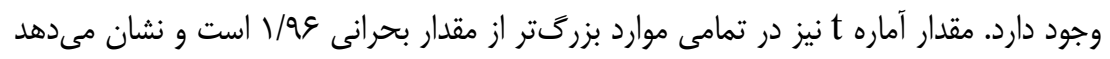


ابعاد برون داد بهدرستى اين سازه را مورد سنجش قرار مى دهند. همجنين، بار عاملى مرتبه دوم هر

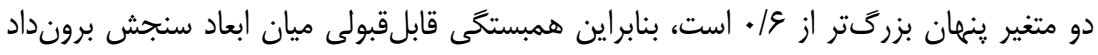

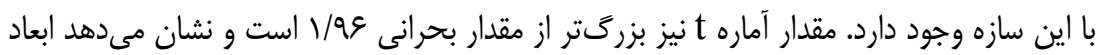
برونداد بهدرستى اين سازه را مىسنجند.

جدول 9: خلاصه نتايج تحليل عاملى تاييدى مرتبه دوم سازه برونداد و شاخصهاى برازش

\begin{tabular}{|c|c|c|c|c|c|c|c|}
\hline RMSEA & $\frac{\chi^{2}}{d f}$ & آماره آزمون & بازة بارهاى عاملى & شرسماره & كويههاد & متغيرهاى & سازه \\
\hline \multirow{2}{*}{ 年/ } & \multirow{2}{*}{$1 / 94$} & & $\cdot / 9 \mathrm{~V}-\cdot / \Lambda \mathrm{r}$ & $1-19$ & 19 & & \multirow{2}{*}{ برونداد } \\
\hline & & $G / V \Lambda-V / \cdot r$ & $\cdot / 9 \mathrm{~V}-\cdot / \mathrm{AT}$ & $r \cdot-r V$ & 11 & كار ايى & \\
\hline
\end{tabular}

شاخصهاى برازش نيز مقادير مطلوبى را نشان مىدهند. شاخص برازش RSMEA برابر

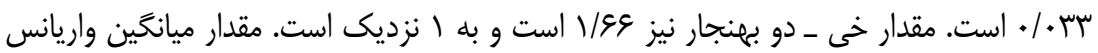

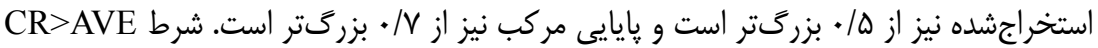
نيز در تمامى موارد برقرار است.

يافتههاى تحليل عاملى سازههاى اصلى و فرعى

سه سازه اصلى در اين يزوهش وجود دارند: درونداد، برونداد، و فرايند. سازه درونداد شامل

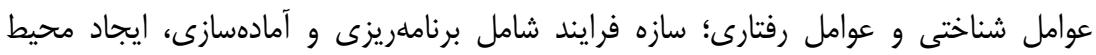
يادگيرى مناسب، آموزش، و ايفاى مسئوليتهاى حرفهاى؛ و سازه برونداد نيز شامل اثربخشى و

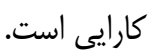


جدول • ا: نتايج تحليل عاملى تاييدى سازههاى اصلى و شاخصهاى برازش

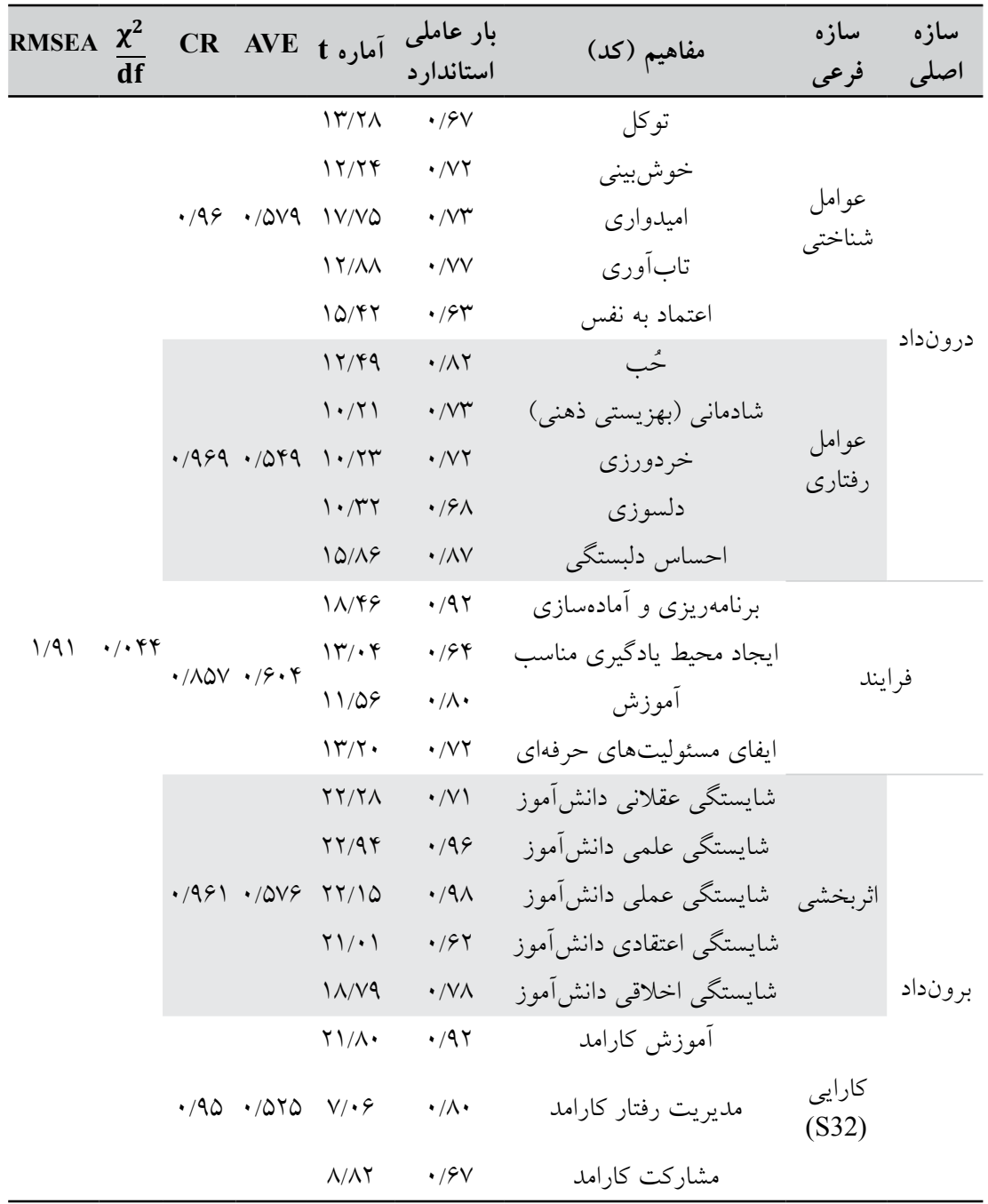

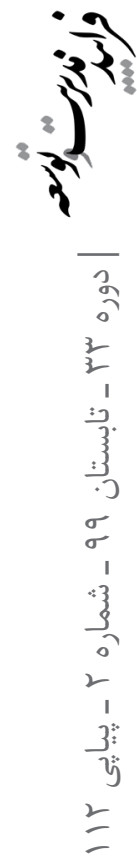

شاخصهاى برازش نيز مقادير مطلوبى را نشان مىدهند. شاخص برازش RSMEA برابر

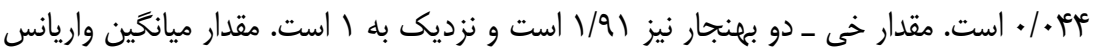
استخراجشده نيز از ه/ • بزرگتر است و پايايى مركب نيز از V/ • بزرگتر است. شرط CR>AVE نيز در تمامى موارد برقرار است. 
استنتاج مدل نهايى ثيزوهش

با توجه به بررسى هملجانبه در مدلهاى موجود در زمينه بهرهورى منابع انسانى و بر اساس مدل مفهومى نهايع يزوهش، مدل سوترمايستر' (19V9)، مى تواند به عنوان مدل يايهاى براى اقتباس و استقرار

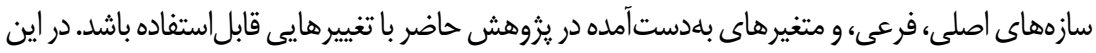
مدل، عوامل نزديكتر به مركز دايره، اثر بيشترى بر بهرهورى كاركنان دارند (Sutermeister, 1976).

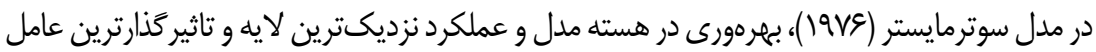
بر بهرهورى است و هر متغيرى كه از هسته دايره فاصله بيشترى مى گيرد، اثر كمترى بر بهرهورى دارديا. با اقتباس از مدل سوترمايستر (9V9)، در مدل نهايى يزوهش روابط سازههاى اصلى، فرعى، و متغيرهاى

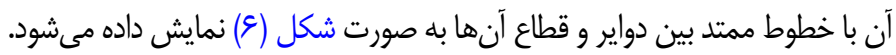

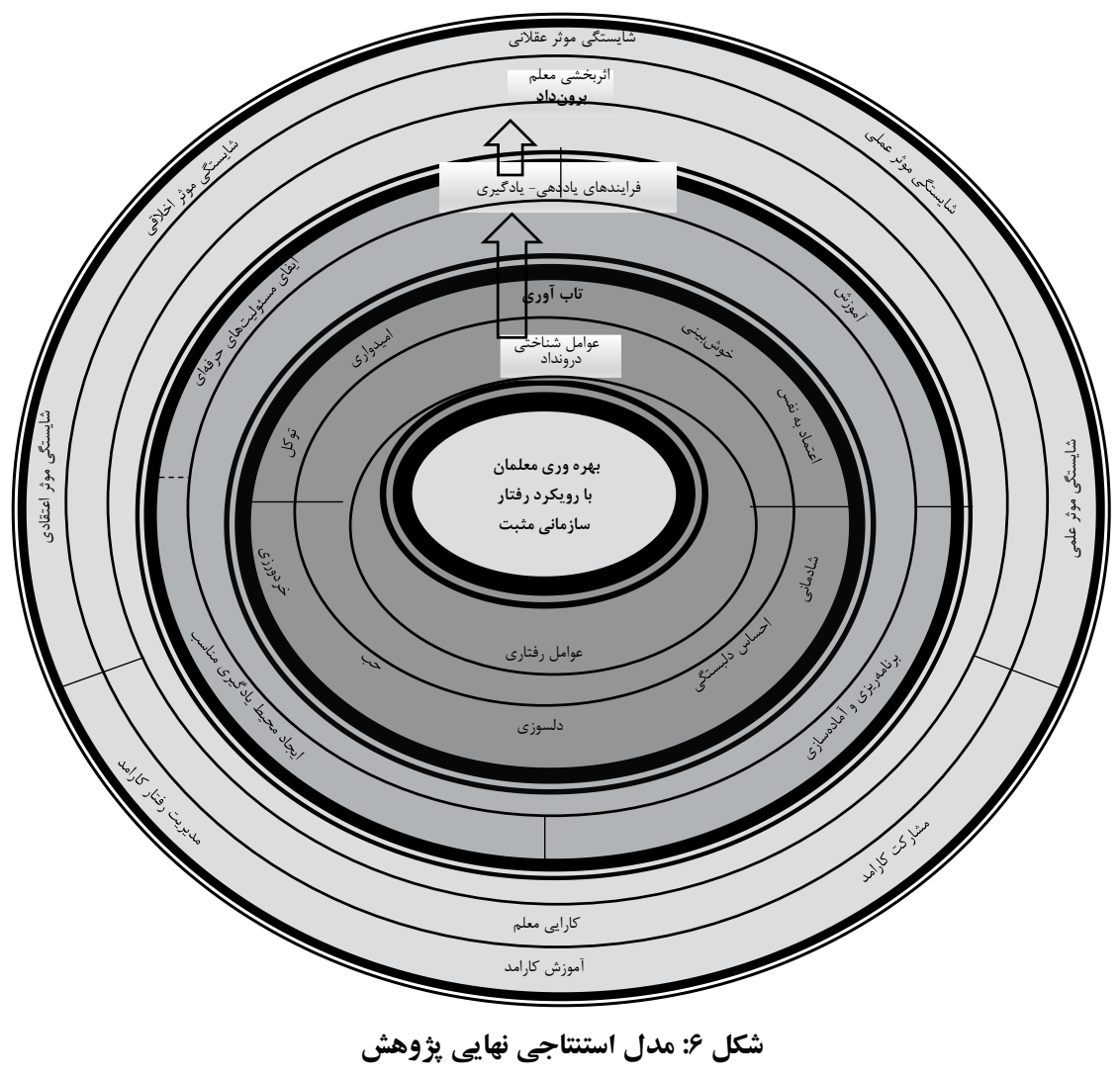

1. Sutermeister 


\section{بحث و نتيجه Fيرى}

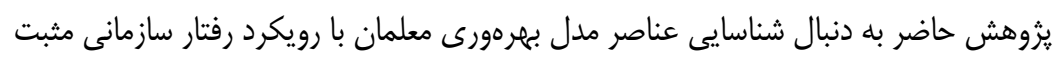

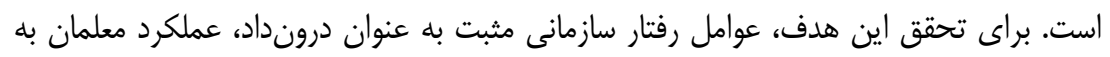

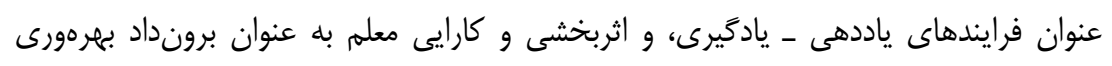

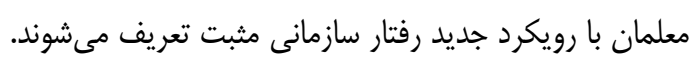

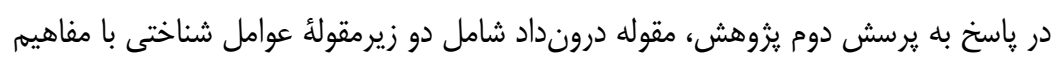

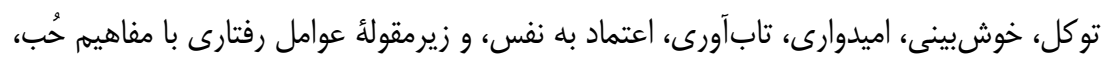

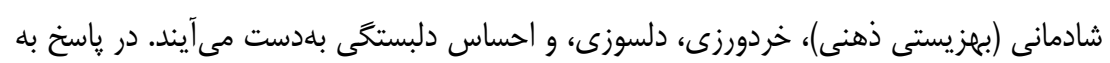

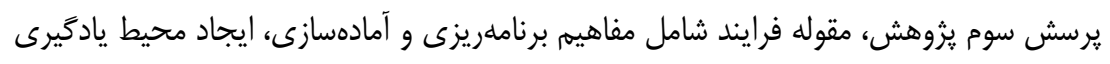

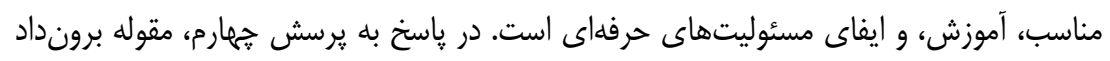

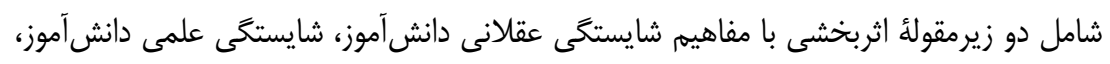

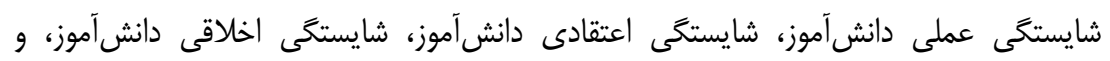

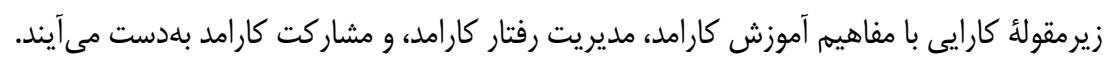

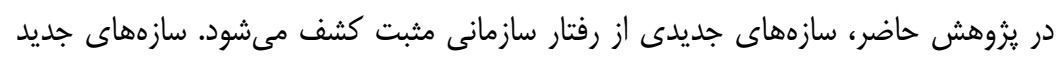

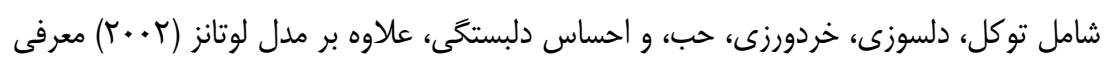

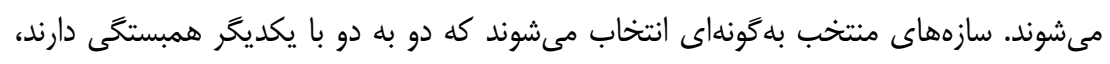

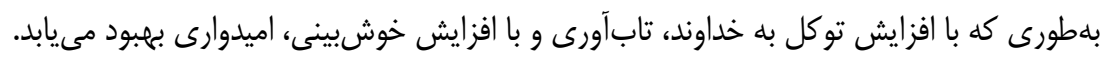

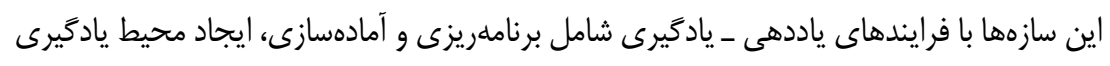

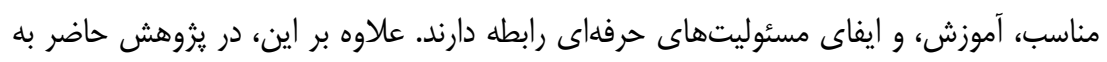

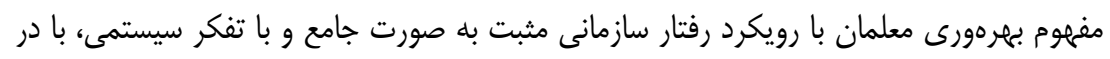

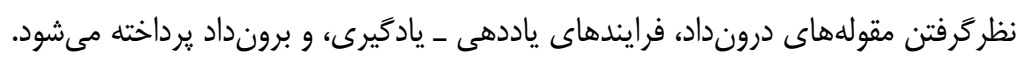

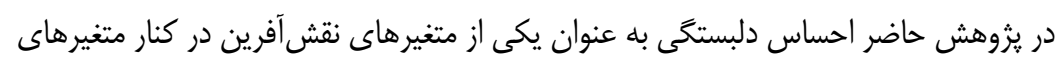

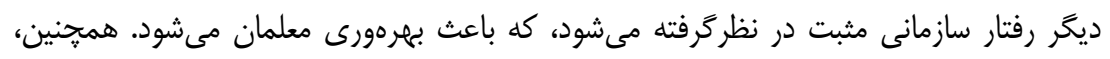

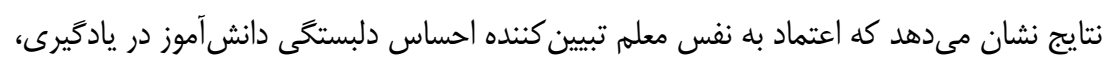

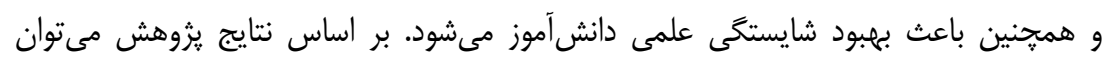

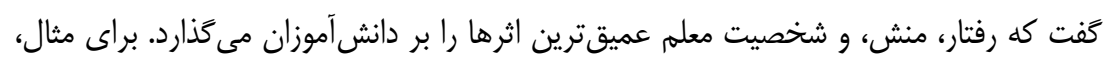

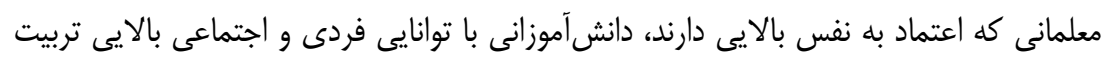


مى كنند و زمانى كه فرصتهاى مناسبى براى ايجاد روابط دوستانه و صميمانه در مدرسه بين

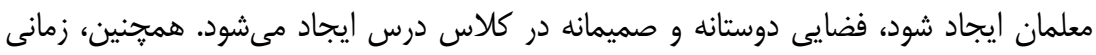

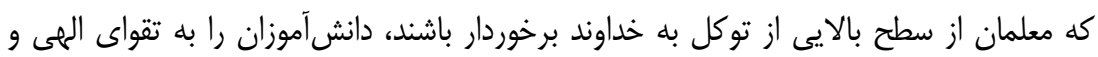

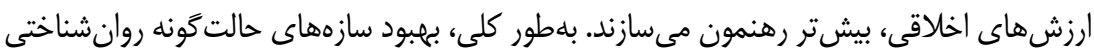

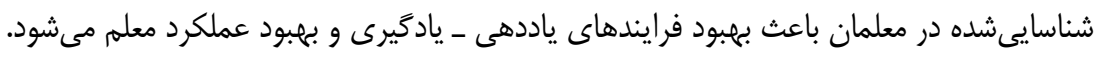
اهميت متغيرهاى رفتار سازمانى مثبت را مىتوان در نقشى كه بر عملكرد و بهرهورى معلمان

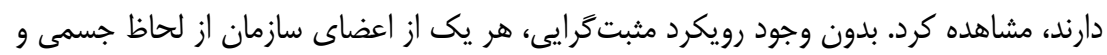

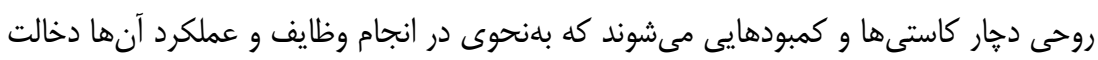
دارد، و اين امر اثربخشى و كارايى معلمان را كه براى تحقق اهداف عالى سازمان مورد نظر است،

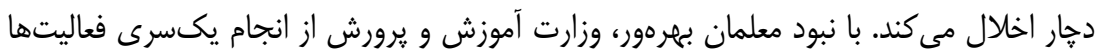
و كاركردهاى روزمره، با وجود صرف هزينههاى هنكفت مادى و انسانى در اين وزارتخانه محروم

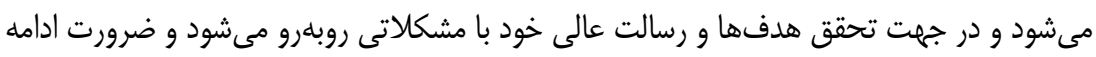
فعاليت آن زير سوال مىرود.

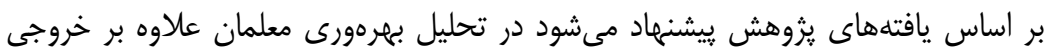

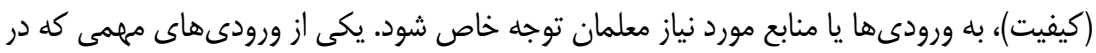

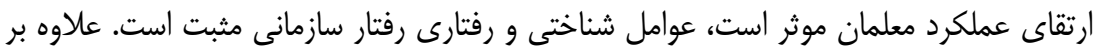

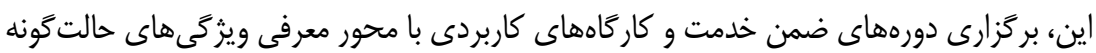
روانشناختى و راهكارهاى بهبود آن، و همجنين شناساندن فرايندهاى ياددهى - ياديّيرى و

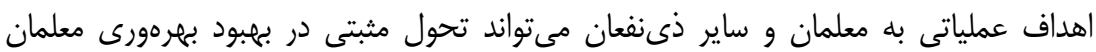
ايجاد نمايد. از طرفى، شاخصهاى شناسايىشده اثربخشى و كارايى را مىتوان براى اندازهگيرى

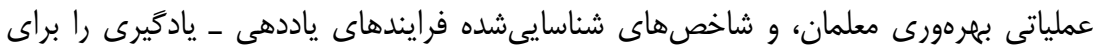
تعيين شاخصهاى ارزيابى عملكرد ساليانه معلمان استفاده نمود. همجنين، بايد به نكته مهمم توجه

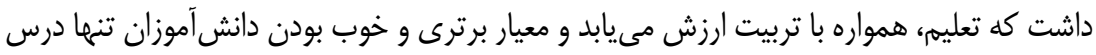

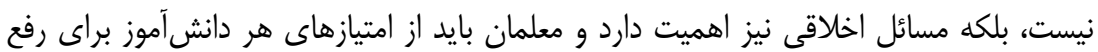

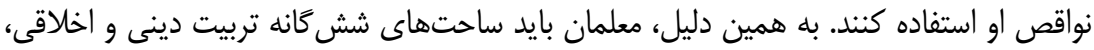
سياسى و اجتماعى، زيستى و بدنى، هنرى و زيباشناختى، اقتصادى و حرفهاى، و علمى و فناورى را بلهور متوازن مورد توجه قرار دهند. براى يزوهشهاى بعدى توصيه مىشود علاوه بر معلمان به ساير كاركنان وزارت آموزش دورن 
و يرورش از قبيل مديران، معاونان، و مشاوران مدارس و كارمندان ستادى ادارهها نيز برداخته

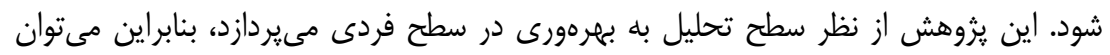

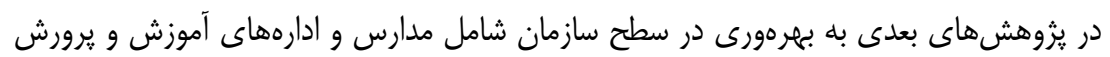

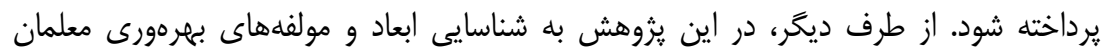

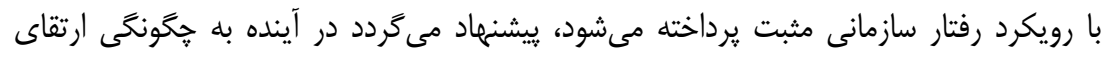

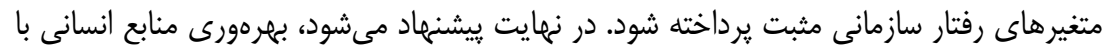

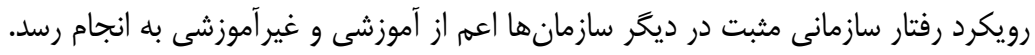

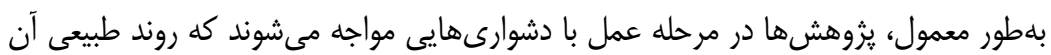

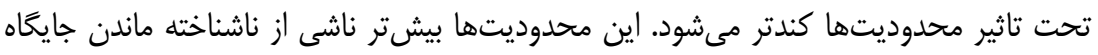

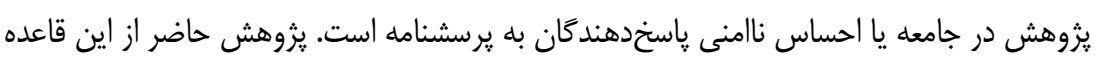

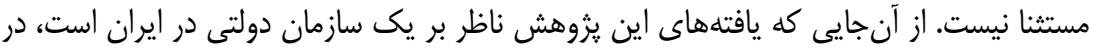

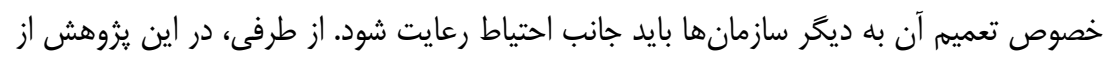
روش تحليل عاملى تاييدى براى روايى سازهها و از مدليابى معادلههاى ساختارى براى آزمون

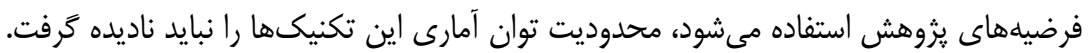

احمدى، عباداله (هوسج). رابطه خلاقيت و نوآورى با بهرهورى منابع انسانى. ثشريه علمى رهيافتى نو در

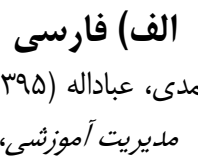

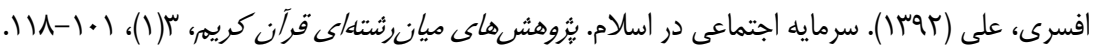

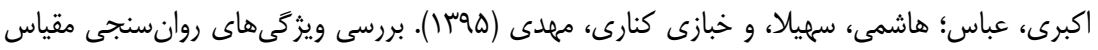

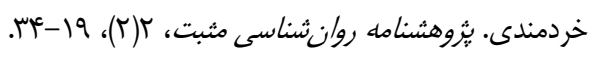

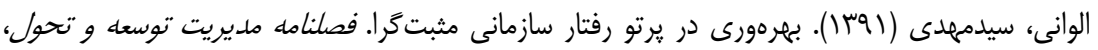
. $9-1$ () (1)

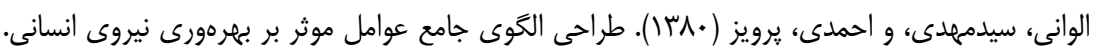

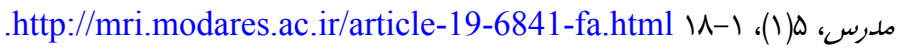

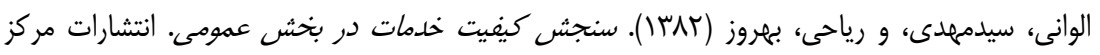
آموزش و تحقيقات صنعتى ايران.

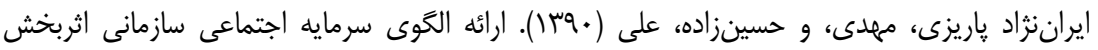


متناسب با سازمانهاى دولتى استان خراسان رضوى. خطمشى نذارى عمومى در مديريت، ؟(T)، با.

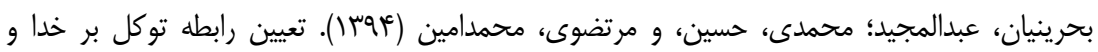

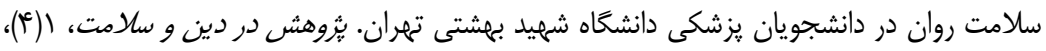
.https://doi.org/10.22037/jrrh.v1i4.9463 r--1r

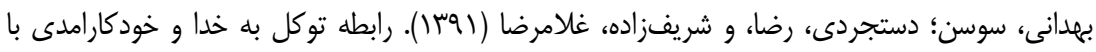

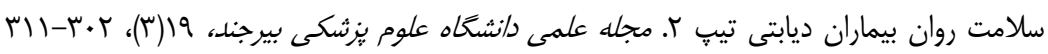
.http://journal.bums.ac.ir/article-1-1194-fa.html

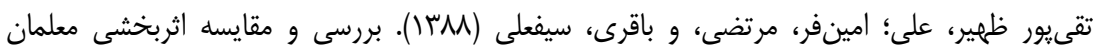

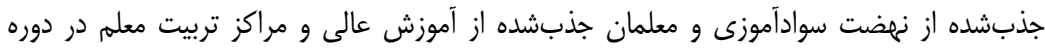

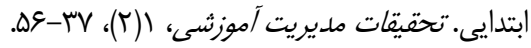

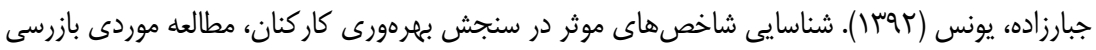

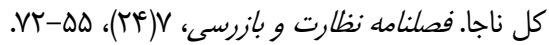

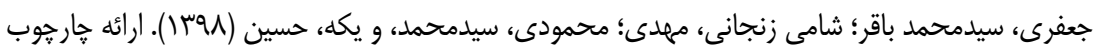

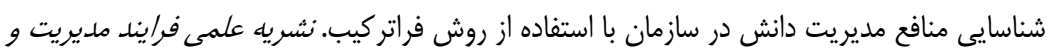

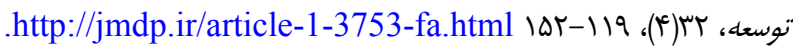

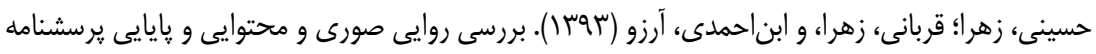

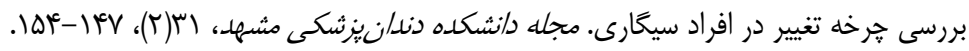

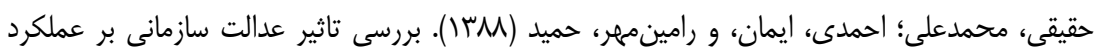

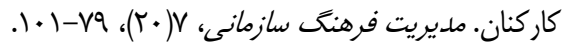

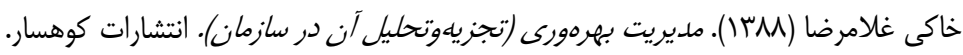

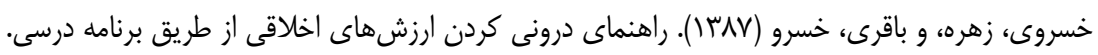

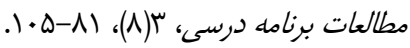

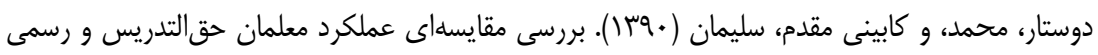

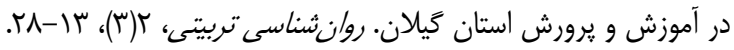

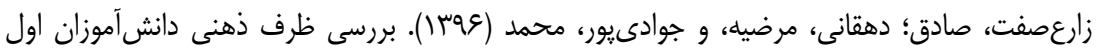

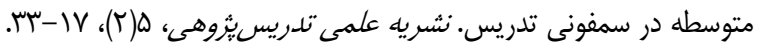

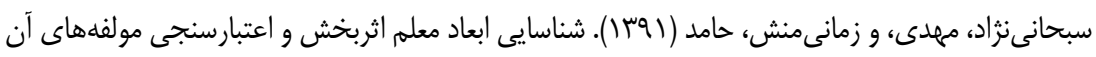

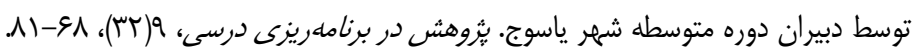

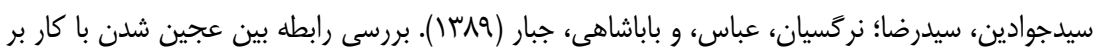

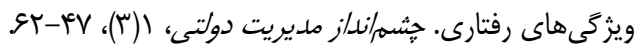

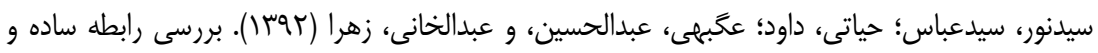

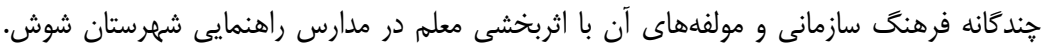




$$
\text { توسعه آموزش جندى ثشايور، س(ץ)، وץ-وس. }
$$

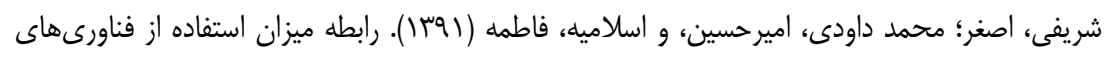

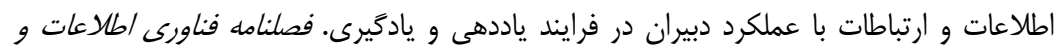

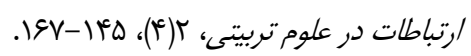

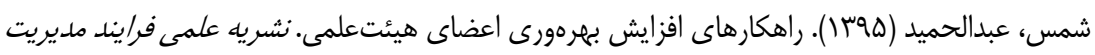

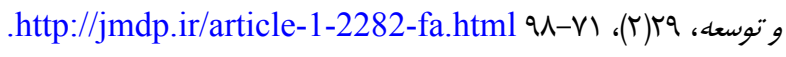

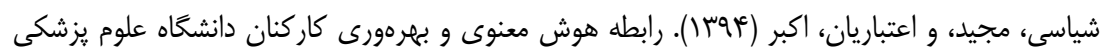

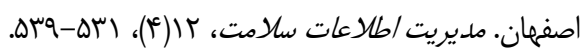

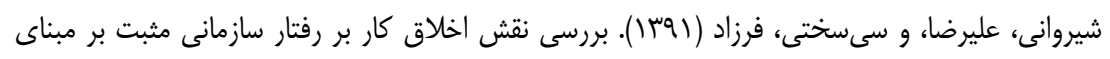

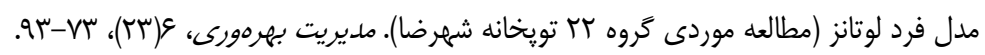

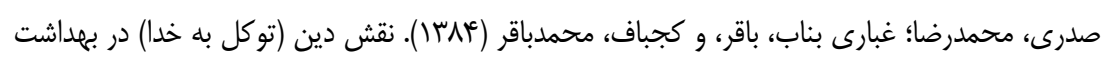

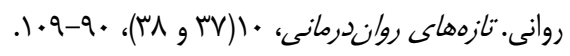

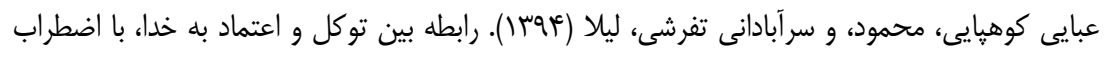

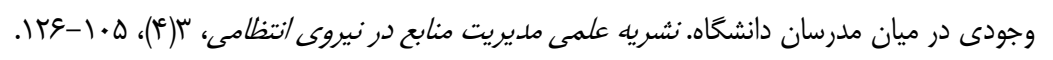

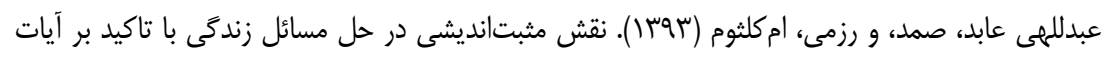

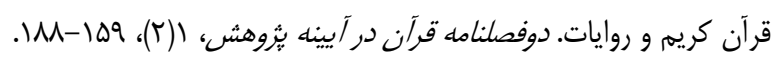

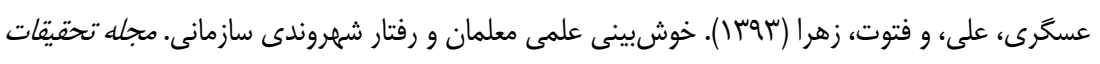

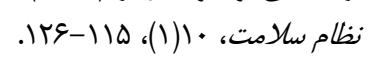

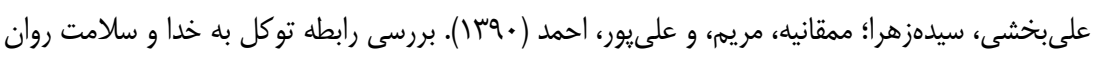

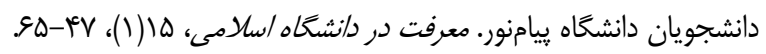

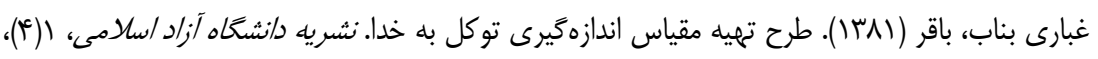
r. +19

فاضلى كبريا، حامد؛ صفرزاده، حسين، و حسنزاده، مسعود ( (9 (1). طراحى مدل مفهومى سرمايه اجتماعى

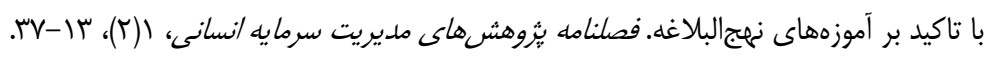

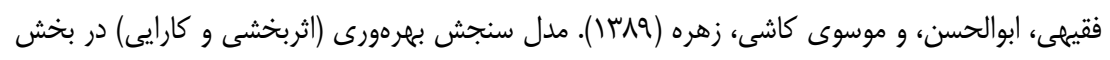

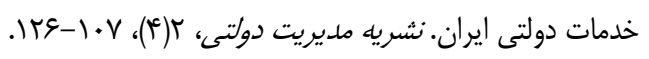

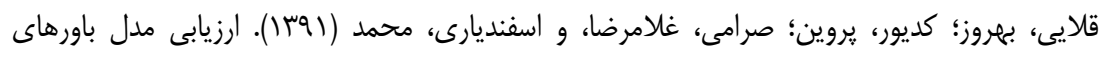

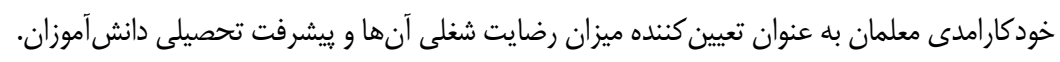

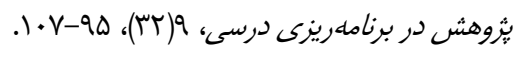

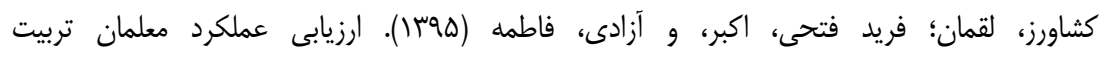
بدنى با استفاده از بازخورد • VT درجه. .http://ntsmj.issma.ir/article-1-629-fa.html

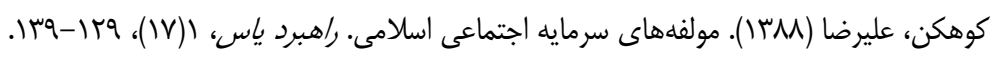




$$
\begin{aligned}
& \text { لنكَرى، مرضيه؛ سليمانيور عمران، محبوبه، و اسماعيلى شاد، بهرنح (هوسا). بررسى رابطه عجين شدن }
\end{aligned}
$$

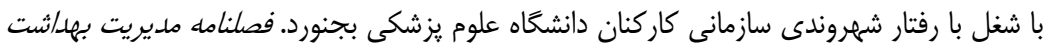

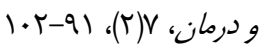

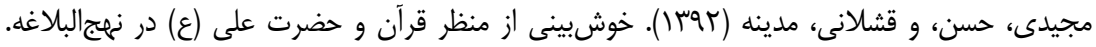

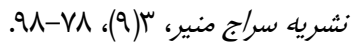

محمديان شريف، كويستان؛ غريبى، حسن، و حبيبى كليبر، رامين (هوسا). مطالعه نيمرخ شخصيتى، منار،

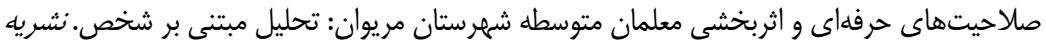

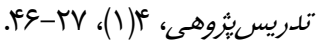

معروف، يحيى، و شريفىراد، سمانه (זوسا). نقش توكل در تامين سلامت روانى انسان. مجله تحقيقات

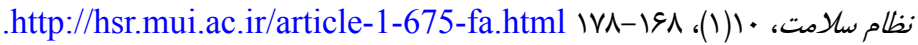

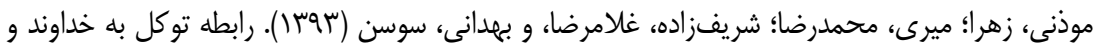

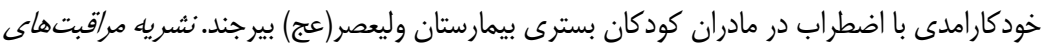
نوين، Iاس()، IIV-r|r

ميرغفورى، سيدحبيباله، و صيادى، حسين (INAV). شناسايى، تجزيلوتحليل و رتبلهبندى عوامل موثر بر

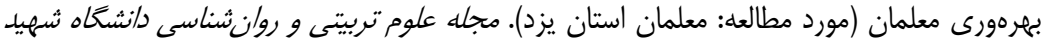

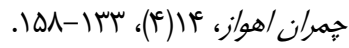

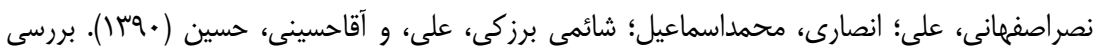

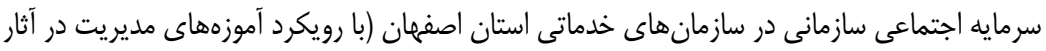

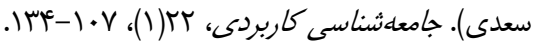

Arjmandi Nejad, A., Yaghoubi, N. M., Doaei, H., \& Rowshan, S. A. (2016). Exploring the Dimensions and Components of Islamic Values Influencing the Productivity of Human Resources From the Perspective of Mashhad Municipality Employees. Procedia-Social and Behavioral Sciences, 230(1), 379-386. https://doi.org/10.1016/j.sbspro.2016.09.048.

Avey, J. B., Luthans, F., Hannah, S. T., Sweetman, D., \& Peterson, C. (2012). Impact of Employees' Character Strengths of Wisdom on Stress and Creative Performance. Human Resource Management Journal, 22(2), 165181. https://doi.org/10.1111/j.1748-8583.2010.00157.x.

Azadeh, A., \& Zarrin, M. (2016). An Intelligent Framework for Productivity Assessment and Analysis of Human Resource from Resilience Engineering, Motivational Factors, HSE and Ergonomics Perspectives. Safety Science, 89(1), 55-71. https://doi.org/10.1016/j.ssci.2016.06.001.

Bakker, A. B., \& Schaufeli, W. B. (2008). Positive Organizational Behavior: 
Engaged Employees in Flourishing Organizations. Journal of Organizational Behavior: The International Journal of Industrial, Occupational and Organizational Psychology and Behavior, 29(2), 147-154. https://doi.org/10.1002/job.515.

Bridglall, B. L., Caines, J., \& Chatterji, M. (2014). Understanding Validity Issues in Test-Based Models of School and Teacher Evaluation. Quality Assurance in Education, 22(1), 19-30. https://doi.org/10.1108/QAE-122013-0053.

Büssing, A., Recchia, D. R., \& Baumann, K. (2015). Reliance on God's Help Scale as a Measure of Religious Trust - A Summary of Findings. Religions, 6(4), 1358-1367. https://doi.org/10.3390/rel6041358.

Chang, J., Fresco, J., \& Green, B. (2014). The Development and Validation of the Compassion of Others' Lives Scale (the COOL Scale). International Journal of Humanities and Social Science, 4(5), 33-42.

Dickie, C. (2009). Exploring Workplace Friendships in Business: Cultural Variations of Employee Behaviour. Research \& Practice in Human Resource Management, 17(1), 128-137.

Donaldson, S. I., \& Ko, I. (2010). Positive Organizational Psychology, Behavior, and Scholarship: A Review of the Emerging Literature and Evidence Base. The Journal of Positive Psychology, 5(3), 177-191. https://doi.org/10.1080/17439761003790930.

Doyle, J. P., Filo, K., Lock, D., Funk, D. C., \& McDonald, H. (2016). Exploring PERMA in Spectator Sport: Applying Positive Psychology To Examine the Individual-Level Benefits of Sport Consumption. Sport Management Review, 19(5), 506-519. https://doi.org/10.1016/j.smr.2016.04.007.

Fadardi, J. S., \& Azadi, Z. (2017). The Relationship between Trust-In-God, Positive and Negative Affect, and Hope. Journal of Religion and Health, 56(3), 796-806. https://doi.org/10.1007/s10943-015-0134-2.

Geiman, M. (2016). A Multiple Case Study of the Influence of Positive Organizational Behavior on Human Resources. (Doctor of Philosophy in Management), Walden University.

Ghobari Bonab, B., \& Koohsar, A. A. H. (2011). Reliance on God as a Core Construct of Islamic Psychology. Procedia-Social and Behavioral Sciences, 30(1), 216-220. https://doi.org/10.1016/j.sbspro.2011.10.043.

Glück, J., König, S., Naschenweng, K., Redzanowski, U., Dorner, L., \& Strasser, I. (2015). State Wisdom vs. Trait Wisdom: Do Situations Influence Wisdom More than Individuals Do? Paper Presented At the Gerontologist, Oxford University Press.

Goe, L., Bell, C., \& Little, O. (2008). Approaches to Evaluating Teacher Effective- 
ness: A Research Synthesis. National Comprehensive Center for Teacher Quality. Goetz, J. L., Keltner, D., \& Simon-Thomas, E. (2010). Compassion: An Evolutionary Analysis and Empirical Review. Psychological Bulletin, 136(3), 351-374. https://doi.org/10.1037/a0018807.

Greene, J. A., \& Brown, S. C. (2009). The Wisdom Development Scale: Further Validity Investigations. The International Journal of Aging and Human Development, 68(4), 289-320. https://doi.org/10.2190/AG.68.4.b.

Hafizi, S., Rosmarin, D. H., \& G. Koenig, H. (2014). Brief Trust/Mistrust in God Scale: Psychometric Properties of the Farsi Version in Muslims. Mental Health, Religion \& Culture, 17(4), 415-420. https://doi.org/10.1080/13674676.2013.816942.

Hanushek, E. A., \& Ettema, E. (2017). Defining Productivity in Education: Issues and Illustrations. The American Economist, 62(2), 165-183. https://doi.org/10.1177/0569434516688207.

Harris, D. N., \& Sass, T. R. (2014). Skills, Productivity and the Evaluation of Teacher Performance. Economics of Education Review, 40(1), 183-204. https://doi.org/10.1016/j.econedurev.2014.03.002.

Heap, J. (1992). Productivity Management: A Fresh Approach: Cassell.

Jitsoonthornchaikul, M. (2015). Seven Steps with Individual Wisdom Development. Journal of Economics. Business and Management, 3(10), 1009-1012.

Kahraman, C. (2008). Fuzzy Multi-Criteria Decision Making: Theory and Applications with Recent Developments (Vol. 16): Springer Science \& Business Media.

Larson, M. D., Norman, S. M., Hughes, L. W., \& Avey, J. B. (2013). Psychological Capital: A New Lens for Understanding Employee Fit and Attitudes. International Journal of Leadership Studies, 8(1), 28-43.

Li, W. (2002). A Positive Organizational Behavior Approach to Work Motivation: Testing the Core Confidence Model in China. (Doctor of Philosophy in Business Administration), Bangkok University.

Luthans, F. (2002). Invited the Need for and Meaning of Essay Positive Organizational Behavior. Journal of Organizational Behavior, 23(1), 695-706. Luthans, F., \& Avolio, B. J. (2009). The "Point" of Positive Organizational Behavior. Journal of Organizational Behavior: The International Journal of Industrial, Occupational and Organizational Psychology and Behavior, 30(2), 291-307. https://doi.org/10.1002/job.589.

Luthans, F., \& Youssef, C. M. (2004). Human, Social, and Now Positive Psychological Capital Management: Investing in People for Competitive Advantage. Organizational dynamics, 33(2), 143-160.

Luthans, F., \& Youssef, C. M. (2007). Emerging Positive Organizational 
Behavior. Journal of Management, 33(3), 321-349. https://doi.org/10.1177/0149206307300814.

Luthans, F., Avey, J. B., Avolio, B. J., \& Peterson, S. J. (2010). The Development and Resulting Performance Impact of Positive Psychological Capital. Human Resource Development Quarterly, 21(1), 41-67. https://doi.org/10.1002/hrdq.20034.

Luthans, F., Avey, J. B., Avolio, B. J., Norman, S. M., \& Combs, G. M. (2006). Psychological Capital Development: Toward a Micro-Intervention. Journal of Organizational Behavior: The International Journal of Industrial, Occupational and Organizational Psychology and Behavior, 27(3), 387393. https://doi.org/10.1002/job.373.

Luthans, F., Avolio, B. J., Avey, J. B., \& Norman, S. M. (2007). Positive Psychological Capital: Measurement and Relationship with Performance and Satisfaction. Personnel Psychology, 60(3), 541-572. https://doi.org/10.1111/j.1744-6570.2007.00083.x.

Malik, A. (2013). Efficacy, Hope, Optimism and Resilience at WorkplacePositive Organizational Behavior. International Journal of Scientific and Research Publications, 3(10), 1-4.

Malinen, O.-P., Savolainen, H., Engelbrecht, P., Xu, J., Nel, M., Nel, N., \& Tlale, D. (2013). Exploring Teacher Self-Efficacy for Inclusive Practices in Three Diverse Countries. Teaching and Teacher Education, 33(1), 34-44. https://doi.org/10.1016/j.tate.2013.02.004.

Mostajaboldavati, S., Khansanami, F., \& Khansanami, S. (2016). Trust in the Almighty God from the Viewpoint of Psychology and Its Relationship with Self-Confidence. Health, Spirituality and Medical Ethics, 3(4), 45-50. http://jhsme.muq.ac.ir/article-1-84-en.html.

Ndugu, M. M. (2014). Quality and Productivity of Teachers in Selected Public Secondary Schools in Kenya. Mediterranean Journal of Social Sciences, 5(5), 103-113. 10.5901/mjss.2014.v5n5p103.

Organisation for Economic Co-operation and Development (OECD), (2009), Evaluation and Assessment Frameworks for Improving School Outcomes, Common Policy Challenges, Education and Training Policy. http://www.oecd.org/education/school.

Pryce-Jones, J. (2011). Happiness at Work: Maximizing Your Psychological Capital for Success: John Wiley \& Sons.

Rashedi, R., Plante, T. G., \& Callister, E. S. (2015). Compassion Development in Higher Education. Journal of Psychology and Theology, 43(2), 131-139. https://doi.org/10.1177/009164711504300205.

Rezai, H., \& Sabzikaran, E. (2012). Exploring the Effect of Organizational Citizenship Behavior on Human Resources Productivity Enhancement. 
Kuwait Chapter of Arabian Journal of Business and Management Review, 33(842), 1-15.

Robertson-Smith, G., \& Markwick, C. (2009). Employee Engagement: A Review of Current Thinking: Institute for Employment Studies Brighton: Institute for Employment Studies. http://hdl.voced.edu.au/10707/388758.

Scheerens, J., Luyten, H., \& Van Ravens, J. (2011). Perspectives on Educational Quality: Illustrative Outcomes on Primary and Secondary Schooling in the Netherlands: Springer Science \& Business Media.

Schmit, D. E., Muldoon, J., \& Pounders, K. (2012). What is Wisdom? The Development and Validation of a Multidimensional Measure. Journal of Leadership, Accountability and Ethics, 9(2), 39-54.

Searle, T. P., \& Barbuto Jr, J. E. (2013). A Multilevel Framework: Expanding and Bridging Micro and Macro Levels of Positive Behavior with Leadership. Journal of Leadership \& Organizational Studies, 20(3), 274-286. https://doi.org/10.1177/1548051813485133.

Shoshani, A., Steinmetz, S., \& Kanat-Maymon, Y. (2016). Effects of the Maytiv Positive Psychology School Program on Early Adolescents' Well-Being, Engagement, and Achievement. Journal of School Psychology, 57(1), 73-92. https://doi.org/10.1016/j.jsp.2016.05.003.

Sutermeister, R. A. (1976). People and Productivity: McGraw-Hill

Tangen, S. (2005). Demystifying Productivity and Performance. InternationalJournalofProductivityandPerformanceManagement, 54(1),34-46. https://doi.org/10.1108/17410400510571437.

Villavicencio-Ayub, E., Jurado-Cárdenas, S., \& Valencia-Cruz, A. (2014). Work Engagement and Occupational Burnout: Its Relation to Organizational Socialization and Psychological Resilience. Journal of Behavior, Health \& Social Issues, 6(2), 45-55. https://doi.org/10.5460/jbhsi.v6.2.47026.

Wright, T. A. (2003). Positive Organizational Behavior: An Idea whose Time Has Truly Come. Journal of Organizational Behavior, 24(4), 437-442.

Wu, C.-H., \& Fang, W.-C. (2011). Combining the Fuzzy Analytic Hierarchy Process and the Fuzzy Delphi Method for Developing Critical Competences of Electronic Commerce Professional Managers. Quality \& Quantity, 45(4), 751-768. https://doi.org/10.1007/s11135-010-9425-6. 